\title{
Mineralogical assemblages forming at hyperalkaline warm springs hosted on ultramafic rocks : A case study of Oman and Ligurian ophiolites
}

\author{
Valérie Chavagnac \\ GET UMR5563 (CNRS/UPS/IRD/CNES), Université de Toulouse, Observatoire Midi-Pyrénées, Géosciences \\ Environnement Toulouse, Toulouse, France (valerie.chavagnac@get.obs-mip.fr)
}

\section{Georges Ceuleneer}

GET UMR5563 (CNRS/UPS/IRD/CNES), Université de Toulouse, Observatoire Midi-Pyrénées, Géosciences Environnement Toulouse, Toulouse, France

\section{Christophe Monnin}

GET UMR5563 (CNRS/UPS/IRD/CNES), Université de Toulouse, Observatoire Midi-Pyrénées, Géosciences Environnement Toulouse, Toulouse, France

\section{Benjamin Lansac}

GET UMR5563 (CNRS/UPS/IRD/CNES), Université de Toulouse, Observatoire Midi-Pyrénées, Géosciences Environnement Toulouse, Toulouse, France

\section{Guilhem Hoareau}

GET UMR5563 (CNRS/UPS/IRD/CNES), Université de Toulouse, Observatoire Midi-Pyrénées, Géosciences Environnement Toulouse, Toulouse, France

Now at Université de Pau et des Pays de l'Adour, Laboratoire des Fluides Complexes et leurs Réservoirs" UMR CNRS TOTAL 5150, I.P.R.A. Avenue de l'Université, BP 1155, FR-64013 PAU, Cedex, France

\section{Cédric Boulart}

GET UMR5563 (CNRS/UPS/IRD/CNES), Université de Toulouse, Observatoire Midi-Pyrénées, Géosciences Environnement Toulouse, Toulouse, France

Now at Leibniz Institute for Baltic Sea Research, Marine Chemistry Department, Warnemünde, Seestrasse 15, DE-18119, Rostock, Germany

[1] We report on the mineralogical assemblages found in the hyperalkaline springs hosted on Liguria and Oman ophiolites based on exhaustive X-ray diffraction and scanning electron microprobe analyses. In Liguria, hyperalkaline springs produce a thin brownish calcite precipitate that covers the bedrock due to the concomitant atmospheric $\mathrm{CO}_{2}$ uptake and neutralization of the hyperalkaline waters. No brucite and portlandite minerals are observed. The discharge of alkaline waters in Oman ophiolite forms white-orange precipitates. Calcium carbonate minerals (calcite and/or aragonite) are the most abundant and ubiquitous precipitates and are produced by the same mechanism as in Liguria. This process is observed as a thin surface crust made of rhombohedral calcite. Morphological features of aragonite vary from needle-, bouquet, dumbbell-, spheroidal-like habitus according to the origin of carbon, temperature, and ionic composition of the hyperalkaline springs, and the biochemical and organic compounds. Brucite is observed both at hyperalkaline springs located at the thrust plane and at the paleo-Moho. The varying mixing proportions between the surface runoff waters and the hyperalkaline ones control brucite precipitation. The layered double hydroxide minerals occur solely in the vicinity of hyperalkaline springs emerging within the bedded 
gabbros. Finally, the dominant mineralogical associations we found in Oman (Ca-bearing carbonates and brucite) in a serpentinizing environment driven by the meteoric waters are surprisingly the same as those observed at the Lost City hydrothermal site in a totally marine environment.

Components : 12,440 words, 11 figures, 3 tables.

Keywords : mineralogy; alkaline springs; geochemistry; serpentinization; ophiolite.

Index Terms : 3665 Mineral occurrences and deposits: Mineralogy and Petrology; 3617 Alteration and weathering processes: Mineralogy and Petrology; 3690 Field relationships: Mineralogy and Petrology; 3616 Hydrothermal systems: Mineralogy and Petrology; 0450 Hydrothermal systems: Biogeosciences; 3017 Hydrothermal systems: Marine Geology and Geophysics; 4832 Hydrothermal systems: Oceanography: Biological and Chemical; 8135 Hydrothermal systems: Tectonophysics; 8424 Hydrothermal systems: Volcanology; 8486 Field relationships: Volcanology; 1039 Alteration and weathering processes: Geochemistry; 1034 Hydrothermal systems: Geochemistry; 1090 Field relationships: Geochemistry.

Received 18 December 2012; Revised 4 April 2013; Accepted 10 April 2013; Published 31 July 2013.

Chavagnac V., G. Ceuleneer, C. Monnin, B. Lansac, G. Hoareau, and C. Boulart (2013), Mineralogical assemblages forming at hyperalkaline warm springs hosted on ultramafic rocks: A case study of Oman and Ligurian ophiolites, Geochem. Geophys. Geosyst., 14, 2474-2495, doi:10.1002/ggge.20146.

Companion to Chavagnac et al. [2013] doi:10.1002/ggge.20146.

\section{Introduction}

[2] The submerged Lost City hyperalkaline hydrothermal system at $30^{\circ} \mathrm{N}$ off the mid-Atlantic ridge drastically changed our understanding of the heat, matter, and element fluxes between the lithosphere and the hydrosphere that were quantified, thus far, on high-temperature hydrothermal vents. This system which is hosted on extensively altered peridotite, called serpentinites, is none like previously seen at the mid-ocean ridges, exhibiting $60 \mathrm{~m}$ tall actively venting carbonate chimneys [Kelley et al., 2001, 2005; Ludwig et al., 2006] and displaying identical morphology to the $14 \mathrm{~m}$ tall carbonate chimney found at the Prony Bay (New Caledonia), hosted on coastal obducted peridotite [Launay, 1981; Launay and Fontes, 1985]. These carbonate chimneys contrast radically to the high-temperature ones being essentially made of sulfide and sulfate minerals [Halbach et al., 2003], but the emitted hydrothermal fluids, although being of much lower temperature, are still enriched in dissolved gases such as hydrogen and methane [Neal and Stanger, 1983; Fritz et al., 1992; Sano et al., 1993; Proskurowki et al., 2008; Proskurowski, 2011; Boulart et al., 2012].

[3] On land, percolation of meteoric waters through obducted peridotites also leads to the formation of secondary mineralogical assemblages typical of serpentinization reactions of which serpentine and magnetite are common markers [Neal and Stanger, 1984; Mével, 2003; Bach et al., 2006]. The crystal- lization of these minerals is contemporaneous with the production of hydrogen and high $\mathrm{pH}$ waters of the $\mathrm{Ca}-\mathrm{OH}$ type that may discharge at the surface under adequate hydrologic conditions. These hyperalkaline waters are characterized by low to nil magnesium concentrations as well as low dissolved inorganic carbon (DIC) contents, while being strongly enriched in calcium [Cipolli et al., 2004; Sader et al., 2007; Kelemen and Matter, 2008; Matter and Kelemen, 2009; Chavagnac et al., 2013]. During the alteration of mafic to ultramafic rocks by meteoric waters and seawater, the concomitant $\mathrm{Mg}$ decrease and $\mathrm{Ca}$ increase in the fluid is related to the destabilization of primary minerals such as olivine into serpentine (for $\mathrm{Mg}$ ) and pyroxene into tremolite (for Ca) [Alt, 1995]. At the discharge sites (i.e., warm springs), the $\mathrm{Ca}-\mathrm{OH}$ type waters get into contact with the atmosphere, they can evaporate when the flow is sluggish, or they can mix with continental surface runoff being $\mathrm{Mg}-\mathrm{HCO}_{3}$ type. This surface phenomena lead to the formation of numerous secondary mineral precipitates that may cover the river bed or form a thin crust over the bedrock. The deposit resembles calcium carbonate travertine, which are commonly observed at and around subaerial hot springs in continental rift basins, such as Mammoth Hot Springs in Wyoming [Ford and Pedley, 1996; Fouke et al., 2000], Bogoria lake in the Kenya Rift Valley [Renaut and Jones, 1997; Renaut et al., 1999, 2002], and volcanic province of central Italy (Viterbo area; Folk [1994]). Travertines constitute a major group of freshwater carbonates, which can be 
distinguished from one to the other because the origin of the carbon dioxide differs (crustal $\mathrm{CO}_{2}$ degassing versus atmospheric $\mathrm{CO}_{2}$ ). Travertines are directly related to the hydrogeological system of the percolating meteoric water, leading to meteogene versus thermogene travertine, thus displaying diverse arrays of texturally complex deposits. Among them, some travertine are deposited from deeply circulating groundwaters, which discharge as thermal springs but contain negligible thermally generated $\mathrm{CO}_{2}$, as it is the case of the Oman and Liguria ophiolite hyperalkaline springs [Clarke and Fontes, 1990]. At these areas, carbonate formation is controlled jointly by complex inorganic factors such as climatic variation that may restrict meteogene water flow [Pentecost, 1995] and organic factors, as abundant microbial mat communities may provide substrates for mineralization [Folk, 1994; Fouke et al., 2000].

[4] Both submerged and aerial hyperalkaline chimneys share similar morphologies, and, at first glance, the springs share similar chemical features as deduced from the composition of hyperalkaline waters [Kelley et al., 2001; Chavagnac et al., 2013]. The general objectives of this paper are first to report on the mineralogical assemblages found in hyperalkaline warm springs of the Oman and Liguria ophiolites based on exhaustive X-ray diffraction (XRD) and scanning electron microprobe (SEM) analyses and to assess the parameters leading to their formation in link with the geological context. Note that the springs of Oman and Liguria are representative of meteoric-derived hyperalkaline waters mixing with meteoric continental surface runoff.

\section{Geological Setting and Samples}

\subsection{Oman Ophiolite (Sultanate of Oman)}

[5] The Oman ophiolite is one of the largest $\left(\sim 30,000 \mathrm{~km}^{2}\right)$ sections of the oceanic lithosphere exposed on land. It is particularly well preserved because it is not yet dismembered by continental collision between Arabia and Eurasia [Coleman, 1981]. The present exposure of the Oman ophiolite results from the recent Miocene uplift of the Oman range [Glennie et al., 1974], which likely preludes to this future collision [Fournier et al., 2006]. The Oman ophiolite itself is a remnant of the former Tethys ocean [Coleman, 1981] or of a more marginal basin [Pearce et al., 1981].

[6] The present thickness of the ophiolitic nappe (not to be confused with paleostratigraphic thicknesses which can reach about $10 \mathrm{~km}$ ) is poorly constrained. A value of about $5 \mathrm{~km}$ seems a reasonable estimate regarding the structural and gravimetric data [Shelton and Egan, 1991]. The ophiolite is made of two major lithological units: a lower section of residual mantle harzburgites and dunites variably serpentinized (from $100 \%$ to almost $0 \%$, with an average around about 30\%) [e.g., Combe et al., 2006] and including mafic dykes as a minor component [Ceuleneer et al., 1996; Python and Ceuleneer, 2003]. Below the basal thrust plane, lithologies include a $\sim 100 \mathrm{~m}$ thick metamorphic sole made of basaltic lavas and sediments metamorphosed in the amphibolite to greenschist facies and sedimentary rocks essentially including limestones and cherts [Glennie et al., 1974; Ghent and Stout, 1981]. The mantle section is topped with the crustal section that can be divided itself in a lower horizon of layered gabbroic cumulates (troctolites, olivine gabbros, gabbronorites, amphibole, and oxide gabbros) and ultramafic cumulates [wehrlites, pyroxenites, etc.] [e.g., Pallister and Hopson, 1981; Juteau et al., 1988; Lachize et al., 1996; Clénet et al., 2010], and in an upper horizon of extrusive rocks (sheeted diabase dykes and pillow lavas capped with radiolarites) [Pallister, 1981; Alabaster et al., 1982]. The contact between the mantle and the crustal section, commonly referred to as the paleo-Moho, is a major regional lithological discontinuity. It is faulted in many (but not all) places [Abily et al., 2011]. When it is the case, the peridotites suffered a higher than average degree of serpentinization. Away from fault zones, the primary igneous minerals in both mantle and crustal lithologies are variably altered, the mode and intensity of alteration varying according to the paleostratigraphic depth [e.g., Gregory and Taylor, 1981; Nehlig, 1993]. Most of these transformations are attributed to ocean ridge hydrothermal circulation. The secondary mineral assemblages point to a wide range of temperature conditions during hydrothermal water circulation, from about $100^{\circ} \mathrm{C}-200^{\circ} \mathrm{C}$ to much more than $600^{\circ} \mathrm{C}$ [e.g., Leblanc et al., 1991; Benoit et al., 1999; Juteau et al., 2000; Python et al., 2007; France et al., 2009; Abily et al., 2011].

[7] At present, alteration of the ultramafic lithology via the serpentinization reactions is driven by the percolation of meteoric water through fractures. These reactions lead to the formation of hyperalkaline springs that are ubiquitous and numerous over the entire ophiolite belt [Stanger, 1986]. The discharge of alkaline waters forms water pools of an intense blue color that can be seen from far-away and snowlike precipitates that covers the bottom of the pools and wadis (an Arabic word referring to river beds). Alkaline springs occur mostly along or in the vicinity of the two major regional structural discontinuities: the thrust plane at the base of the ophiolite and the 


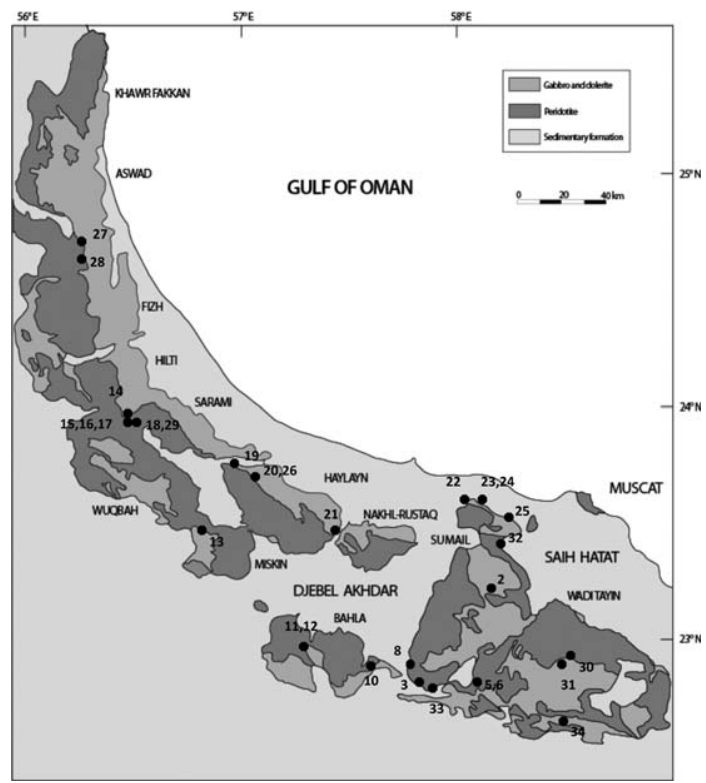

Figure 1. Simplified geological map of the Omani ophiolite (Sultanate of Oman) on which are reported the hyperalkaline springs.

paleo-Moho inside its mass. Some springs seem located (in map) away from these discontinuities, either inside the mantle section or inside the lower crustal section (Figure 1), but might be not so far from the Moho or from the thrust plane in the 3-D world. Alkaline springs are characterized by high $\mathrm{pH}$ values (up to 11.9) and high calcium and hydrogen contents, while being depleted in transition metals, carbon dioxide, and silica [Chavagnac et al., 2013; Boulart et al., 2012; Paukert et al., 2012].

\subsection{Voltri Massif of the Liguria Ophiolite (Italy)}

[8] The Voltri Massif in the Ligurian Alps is the largest ophiolite massif in the Apennines system, located at the most southern sector of the Western Alps and to the north of the Apennines. It represents the remnants of the subducted and exhumed lithosphere of the Piedmont-Ligurian ocean as part of the Mesozoic-Tethys [Vanossi et al., 1984; Brouwer et al., 2002].

[9] The Voltri Group is composed of three main units (Figure 2): (1) The Voltri-Rossiglione unit, essentially made of metasediments and metavolcanics; (2) the Beigua Unit composed of serpentinites with enclaves of eclogitized basalts and gabbros; and (3) the Erro-Tobbio unit considered as the exhumed subcontinental lithospheric mantle composed of serpentinized lherzolites [Hoogerduijn Strating et al., 1993; Hermann et al., 2000]. Based on geothermo- barometry, the uplift the Erro-Tobbio peridotites at high crustal levels occurred by tectonic denudation within an oceanic rift. The tectonic convergence led to the closure of the oceanic basin leading to peridotite subduction and recrystallization under eclogitefacies conditions [Scambelluri et al., 1991].

[10] Locations of the hyperalkaline springs were reported in Marini and Ottonello [2002] and Cipolli et al. [2004]. Most of them (if not all) are in the riverbeds just above the water level. Two of them (GOR34 and GOR35) are located within the ErroTobbio unit, whereas all the others are situated within the upper section of the metamorphized oceanic crustal section (the Beigua Unit). The springs are characterized by high $\mathrm{pH}$ value (up to 11.7) and high calcium, sodium, and methane contents while being depleted in transition metals and silica [Chavagnac et al., 2013; Boulart et al., 2012; Marini and Ottonello, 2002; Cipolli et al., 2004; Schwarzenbach, 2011].

\subsection{Sample Collection}

[11] During three field trips, which took place in December 2008, January 2010, and January 2011, numerous precipitates were collected at or in the vicinity of hyperalkaline springs in the Oman ophiolite. To find the springs has been made quite easy thanks to the extensive data set reported by Stanger [1986] who studied the hydrogeology of the Oman ophiolite and to the Ministry of Water Resources of Oman who kindly provided us their data inventory of water resources. We collected precipitates at 22 sites distributed all over the ophiolite. At the discharge area of hyperalkaline springs, no precipitate was observed. Precipitates were observed when alkaline springs mix with surface runoff waters. We identified three types of

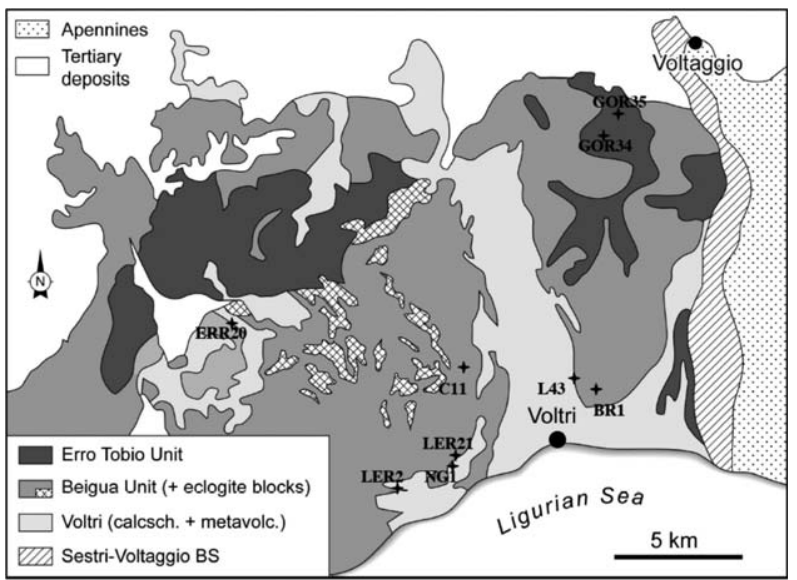

Figure 2. Simplified geological map of the Voltri Massif (Italy) on which are reported the hyperalkaline springs. 
Table 1. Theoretical Chemical Formula of Minerals Found at Hyperalkaline Springs

\begin{tabular}{lc}
\hline Mineral Name & Chemical Formula \\
\hline Calcium carbonate (calcite, aragonite) & $\mathrm{CaCO}$ \\
Brucite & $\mathrm{Mg}(\mathrm{OH})_{2}$ \\
Portlandite & $\mathrm{Ca}(\mathrm{OH})_{2}$ \\
Suolunite & $\mathrm{Ca}_{2} \mathrm{Si}_{2} \mathrm{O}_{5}(\mathrm{OH})_{2}-\mathrm{H}_{2} \mathrm{O}$ \\
Hydrotalcite & {$\left[\mathrm{Mg}_{6} \mathrm{Al}_{2}(\mathrm{OH})_{16}\right]\left[\left(\mathrm{CO}_{3}\right) \cdot 4 \mathrm{H}_{2} \mathrm{O}\right]$} \\
Indigirite & {$\left[\mathrm{Mg}_{2} \mathrm{Al}_{2}(\mathrm{OH})_{2}\right]\left[\left(\mathrm{CO}_{3}\right)_{4} \cdot 15 \mathrm{H}_{2} \mathrm{O}\right]$} \\
Iowaite & {$\left[\mathrm{Mg}_{6} \mathrm{Fe} 2(\mathrm{OH})_{16}\right]\left[\mathrm{Cl}_{2} \cdot 4 \mathrm{H}_{2} \mathrm{O}\right]$} \\
Brugnatellite & {$\left[\mathrm{Mg}_{6} \mathrm{Fe}(\mathrm{OH})_{13}\right]\left[\left(\mathrm{CO}_{3}\right) \cdot 4 \mathrm{H}_{2} \mathrm{O}\right]$} \\
\hline
\end{tabular}

precipitates: (1) those forming a thin crust at the surface of isolated and still basin, (2) structured to unstructured white deposit within the wadi bed, and (3) semiconsolidated white-orange deposit. The samples were collected with a spatula and stored in petri dishes until further mineralogical investigation in the laboratory.

[12] During a field campaign in June 2010, we collected mineral precipitate at 10 out of 19 hyperalkaline springs in the Voltri Massif of the Ligurian ophiolite. Most of the hyperalkaline springs are channeled to the source via a tube, and produced a brownish precipitate that covers the bedrock in close vicinity of the spring water discharges. There is no blue pool and yogurt-like white precipitates as those found in Oman.

[13] Note that the hyperalkaline springs were collected at the same site as mineral precipitates and that a detailed chemical composition of these groundwaters are reported in Chavagnac et al. [2013].

\section{Methods}

[14] All samples were dried at atmospheric conditions before preparation for SEM and XRD analyses, which were carried at the Geosciences Environnement Toulouse laboratory. A small fraction of each sample (a few milligrams) was taken as such and then carbonated before SEM analyses. Morphological features of minerals were obtained by MEB JEOL JSM-6360 LV SEM coupled with an EDS BRUCKER XFlash 5010 system. The accelerating tension was between 10 and $20 \mathrm{kV}$ adjusted according to the sample.

[15] For XRD analyses, a few milligrams of sample was powdered in an agate mortar prior to analyses. Mineralogical associations were determined using XRD [Guillaume et al., 2004; Köster, 1995]. XRD patterns of unoriented powders were obtained with a CPS 120 diffractometer (Co K $\alpha$ radiation at $0.178897 \mathrm{~nm}$, operated at $40 \mathrm{kV}$ and $25 \mathrm{~mA}$ ).

[16] The chemical formula of all identified minerals is listed in Table 1 .

\section{Results}

\subsection{Voltri Massif}

[17] The results of SEM and XRD analyses are reported in Table 2 . The area where the precipitates are observed is extremely limited in space, as shown on Figure 3. The data indicate that calcite is the main mineral to be formed. There is one peculiar site with the occurrence of small grains of native sulfur at site $\mathrm{C} 11$, located within the Beigua Unit (Figures 3a-3c). This site is characterized by low $\mathrm{pH}$ value at 9.45, which is the lowest one in comparison to the other hyperalkaline springs of the Voltri Massif, and also presents the occurrence of white filamentous bacterial mats developing on the bedrock. At site GOR34, calcium carbonate precipitation forms well-developed microterraces on the steep outer face of the slope bedrock (Figure 3d). SEM images of the precipitate show that calcite occurs essentially as hedgehog-like morphology (Figure $3 e)$. At other sites such as GOR35, calcite exhibits rhombohedral and hedgehog-like morphologies (Figures $3 \mathrm{f}$ and $3 \mathrm{~g}$ ) and forms a thin millimeterthick crust covering the bedrock.

\subsection{Oman Ophiolite}

[18] Table 3 summarizes the different minerals identified based on XRD analyses and listed

Table 2. Summary of the Mineralogical Association Found at the Hyperalkaline Springs Located at Voltri Massif

\begin{tabular}{lccc}
\hline Site & Name & X UTM (WGS 84) & Y UTM (WGS 84) \\
\hline C11 & Fiorino & 475768 & 4924028 \\
L43 & Acquasanta & 481622 & 4922794 \\
LER2 & Ponte Arma & 469661 & 4917003 \\
NG1 & Rio Leone & 472767 & 4918911 \\
LER21 & Rio Leone & 472819 & 4919057 \\
BR1 & Rio Branega & 482416 & 4921376 \\
GOR35 & Gorzente (lago Lavagnina) & 483052 & 4938156 \\
GOR34 & Gorzente & 482791 & 4938136 \\
ERR20 & Maddalena (Don Orione) & 460158 & 4928508 \\
\hline
\end{tabular}



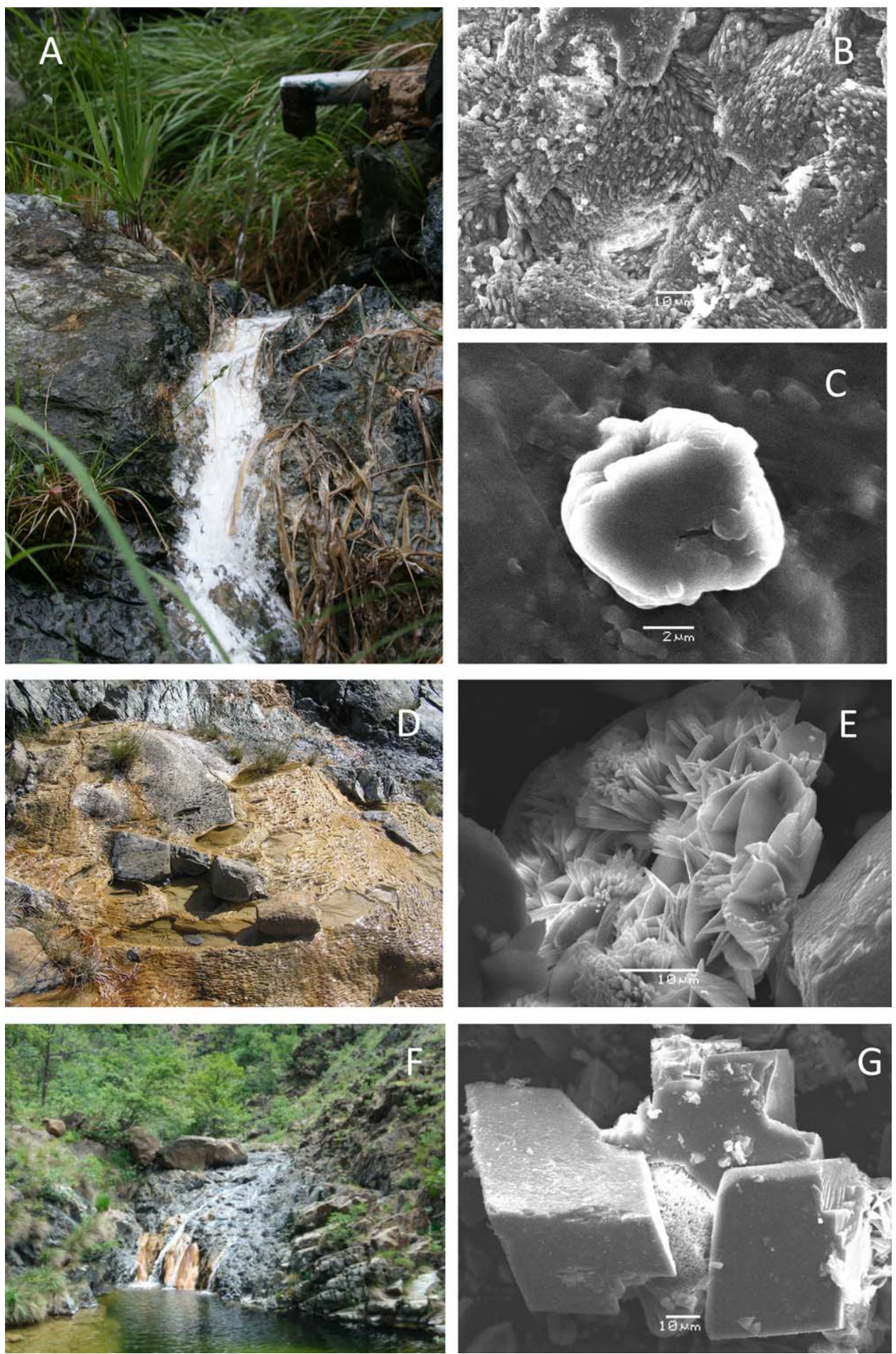

Figure 3. Field photographs of hyperalkaline springs located in the Voltri Massif (a) site C11, (d) site GOR34, (f) site GOR35. EDS-SEM images of the mineral precipitates associated with these discharges: (b) site GOR34, calcite; (c) site C11: native sulfur; (e) Site GOR35: calcite; (g) site GOR35: calcite. [Color figure can be viewed in the online issue, which is available at wileyonlinelibrary.com.]

according to their sampling sites. Three types of minerals were identified: carbonates, hydroxides, and hydrated hydroxides (chloride and carbonatebearing ones) (Table 1 and Figure 4).
[19] First, we list the three types of minerals in the order of their abundance in the deposits. Calcium carbonate minerals are the most abundant and ubiquitous precipitates, as they are present in all 


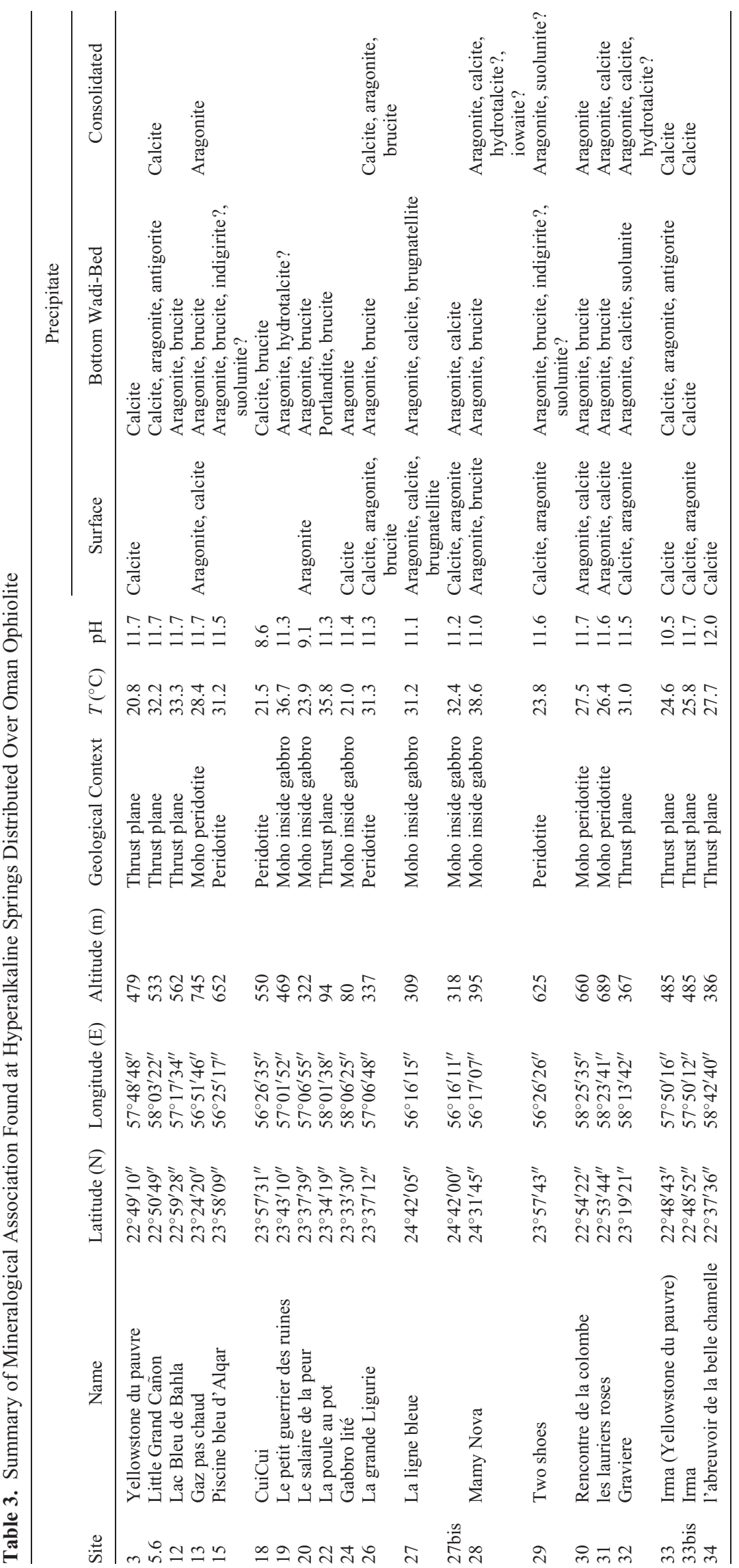




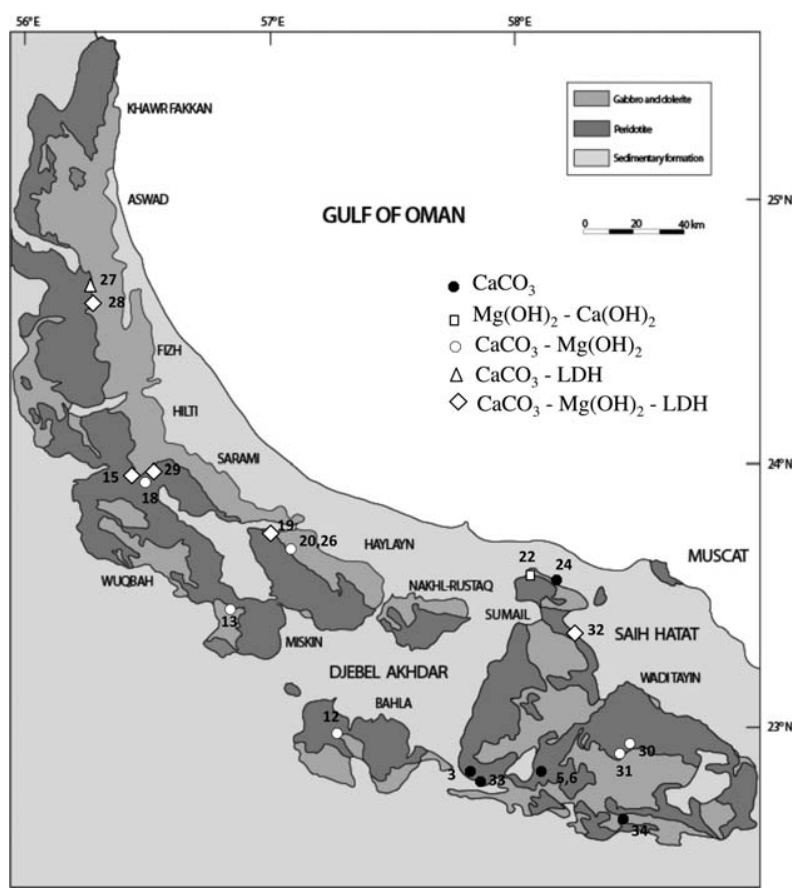

Figure 4. Spatial distribution of the different mineralogical associations found with hyperalkaline springs at the Sultanate of Oman.

alkaline springs. The XRD analyses indicate that they crystallized as calcite or aragonite. There is no evidence for other calcium carbonate polymorphs such as vaterite, for example, which is metastable at atmospheric conditions. They occur as either a thin-surface crust (Figure 5a), composed of calcite (Figure $5 \mathrm{~b}$ ) and of calcite and aragonite (Figure 5c), or as bottom wadi deposit made of aragonite showing various morphologies, i.e., spheroidal (Figure 5d), pyramid (Figure 5e), and bouquet to dumbbell (Figure 5f).

[20] The second type of minerals is the hydroxide. Based on XRD analyses (Figure 6a), they occur either as magnesium-bearing one, i.e., brucite, or as calcium-bearing one, i.e., portlandite (Table 1). Brucite is present at numerous sites distributed over the ophiolite as shown on Figure 4. This mineral exhibits a snowball like structure of $20 \mu \mathrm{m}$ diameter in size (Figure 7b). In comparison, portlandite has been identified at only one place (site 22 "Poule au pot"). It exhibits a fibrous morphology as shown on Figure 7a.

[21] The last type of minerals is the hydrated hydroxide [layered double hydroxide (LDH): hydrotalcite and indigirite $\left(\mathrm{Mg}-\mathrm{Al}-\mathrm{CO}_{3}\right)$, brugnatellite $\left(\mathrm{Mg}-\mathrm{Fe}-\mathrm{CO}_{3}\right)$, and iowaite $\left.(\mathrm{Mg}-\mathrm{Fe}-\mathrm{Cl})\right]$ (Table 1). The LDHs are present at a few hyperalkaline springs as shown on Figure 4. Figure 6b illustrates the XRD spectra obtained on the mineralogical association where LDHs are identified. Figure 7c illustrates the morphology of hydrotalcite and calcium carbonate mineralogical association at site 32 "Gravière" using SEM images. In this example, the calcium carbonates are present as dumbbell-like aragonite and scalenohedral calcite together with hydrotalcite flakes (Figure 7c). Hydrotalcite minerals look like brucite apart from its less well-defined structure defining a gathering of flake rather than a structured snowball habitus (Figure 7d).

[22] Finally, we suspect the occurrence of calcium silicate hydrate (suolunite) at sites 15 and 29 (possibly at site 32 ) based on XRD analyses but was not observed on SEM analyses. Antigorite was found as a detrital mineral at sites 5 and 33, both sites located at the thrust plane.

\section{Discussion}

\subsection{Suolunite: A Rare Calcium Silicate Hydrate}

[23] Calcium silicate hydrate, i.e., suolunite (Tables 1 and 3), was discovered for the first time in the alteration product of ultramafic rocks in Mongolia, near the town Suolun, from which the mineral takes its name [Huang, 1965]. Suolunite is a stable mineral up to $400^{\circ} \mathrm{C}$ at atmospheric pressure but presents several polymorphs depending on the temperature, chemical composition, $\mathrm{pH}$, and redox potential [Shaw et al., 2000; Ho et al., 2009]. In our study, sites 15 and 29 are both hosted on extensively altered peridotites, a couple of hundred meters to the paleo-Moho, and the hyperalkaline springs are expelled within a fault zone above the wadi level. The previous study of Stanger and Neal [1984a] also mentioned the occurrence of suolunite in a similar geological setting. Suolunite's precipitation from serpentinization-derived $\mathrm{Ca}-\mathrm{OH}$ waters is only possible in the absence of any $\mathrm{Mg}$ and $\mathrm{HCO}_{3}$ [Stanger and Neal, 1984a].

\subsection{Hydroxide Minerals}

[24] In the Ligurian ophiolite, the mineralogical analyses did not reveal any magnesium or calcium hydroxide such as brucite and portlandite, respectively. Brucite likely forms as indicated by its supersaturation at high pH [Cipolli et al., 2004; Chavagnac et al., 2013], but in so small quantities that it may be readily washed away by the high river flow and thus does not accumulate. 

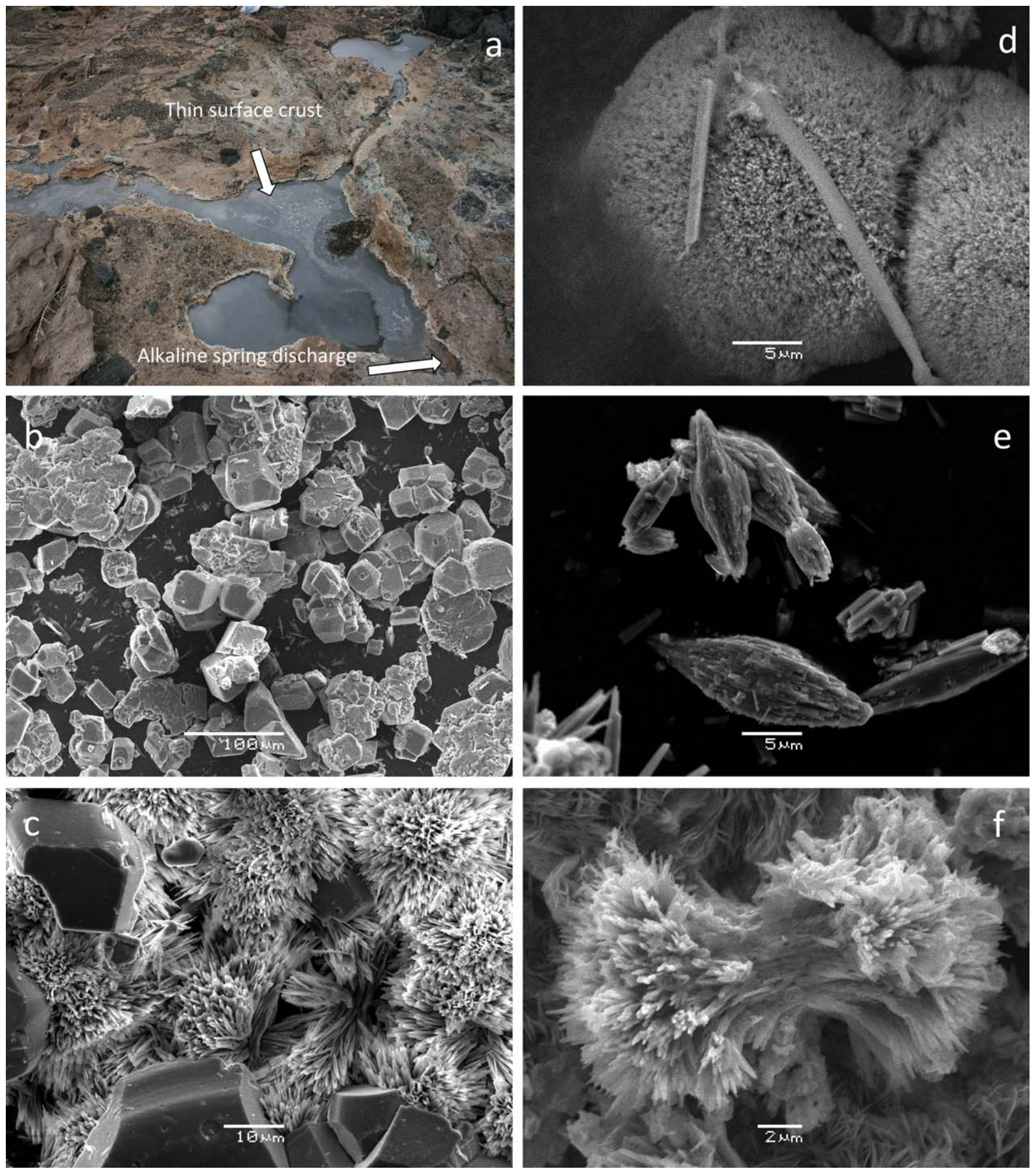

Figure 5. (a) Picture of the alkaline spring presenting a thin surface crust made of calcium carbonate. SEM image of calcium carbonate polymorph and morphologies: (b) calcite formed as a thin surface crust; (c) needle-like aragonite growing on rhombohedral calcite as a thin surface crust; (d) spheroidal-like aragonite; (e) pyramid-like aragonite; (f) bouquet- to dumbbell-like aragonite. [Color figure can be viewed in the online issue, which is available at wileyonlinelibrary.com.]

[25] In the Oman ophiolite, we identified brucite and portlandite, as mentioned earlier in the study of Neal and Stanger [1984a]. Over the 22 sites visited during the course of this study, brucite was identified at 11 of them, which shows a much larger spatial distribution of this mineral than the three out of 21 reported in Neal and Stanger [1984a] (Figure 4). Brucite is observed both at hyperalkaline springs located at the thrust plane and at the paleo-Moho, which are the main 

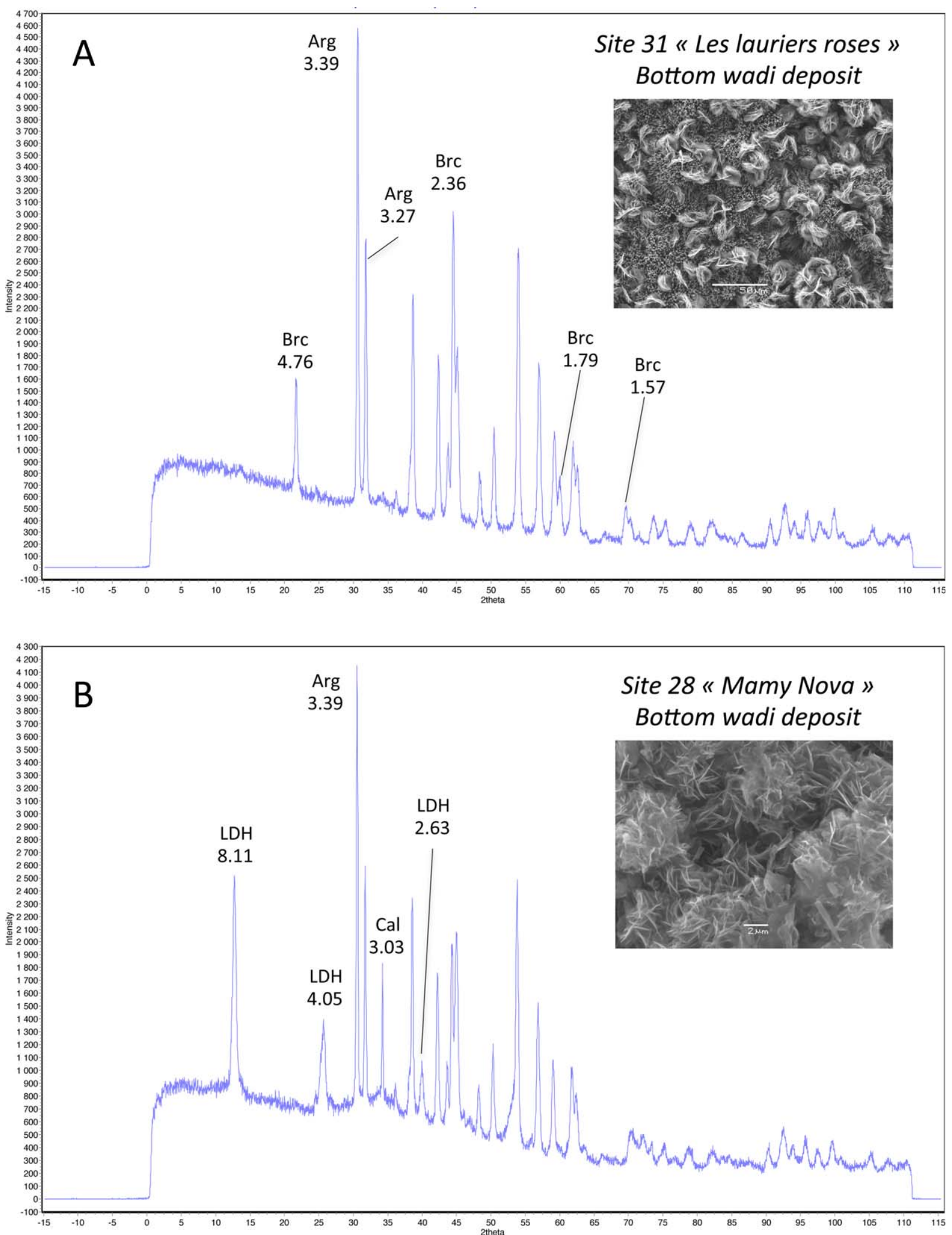

Figure 6. XRD spectra obtained on mineral deposit located at the bottom wadi. (a) Site 31 "Les lauriers roses" where we identify the occurrence of aragonite (Arg) and brucite (Brc). A SEM image illustrates the mineralogical association whereby aragonite exhibits needle-like morphology and brucite snowball morphology. (b) Site 28 "Mamy Nova" where we identify the occurrence of aragonite (Arg), iowaite (LDH) and calcite $(\mathrm{Cal})$. The main peaks of each mineral are noted onto each spectra. [Color figure can be viewed in the online issue, which is available at wileyonlinelibrary.com.] 

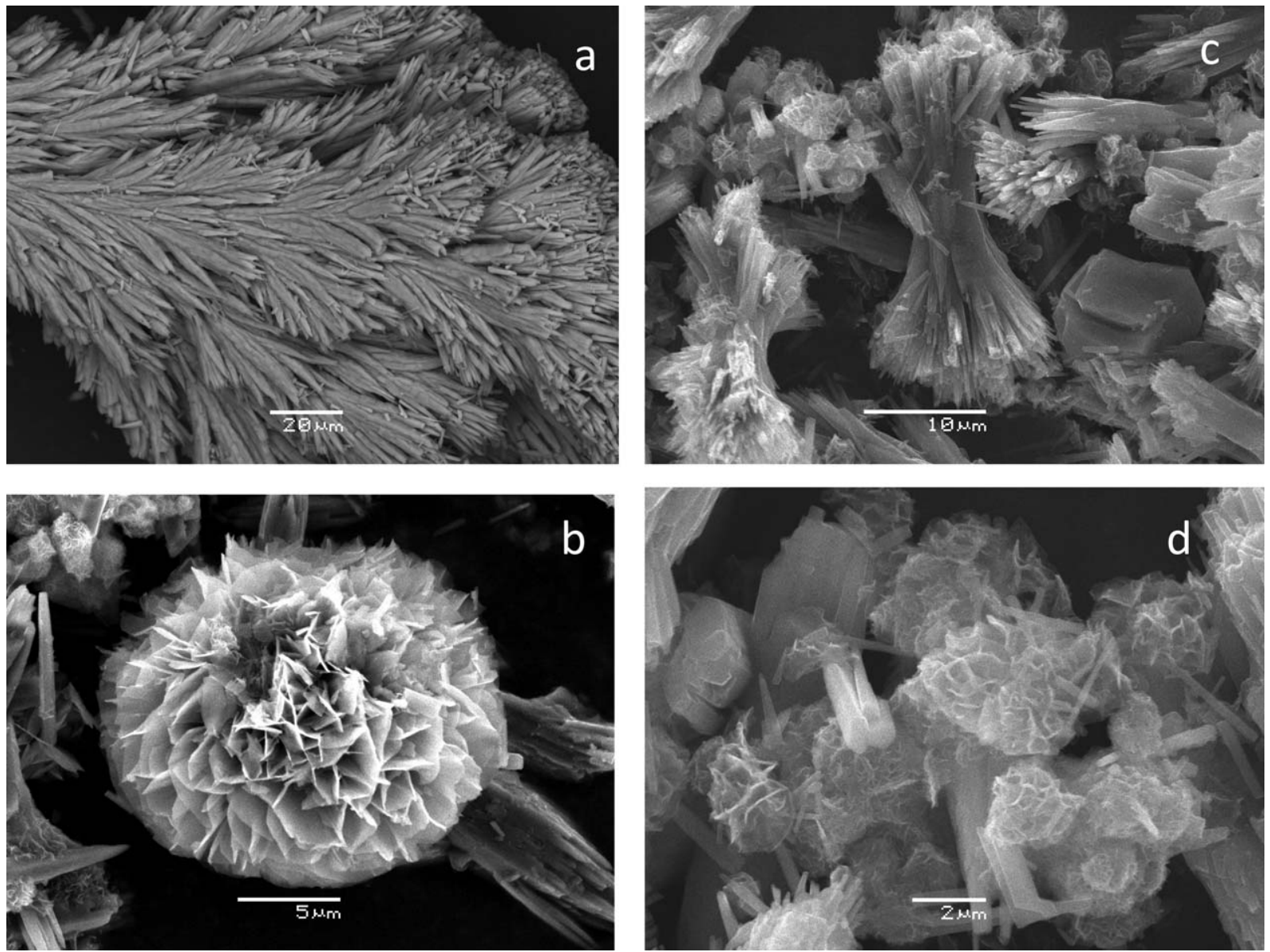

Figure 7. SEM images of hydroxide and LDH minerals collected at the bottom of the wadi. (a) portlandite collected at site 22; (b) brucite collected at site 20; (c) bundle-like morphology of aragonite associated with scalonohedral calcite and hydrotalcite flakes; (d) gathering of hydrotalcite flakes, based on the brucite morphology, as shown in Figure $7 \mathrm{~b}$ but much less crystallized.

hydrological pathways for hyperalkaline spring waters to reach the surface [Chavagnac et al., 2013]. The varying mixing proportions between the $\mathrm{Mg}-\mathrm{HCO}_{3}{ }^{-}$surface runoff waters and the $\mathrm{Ca}$ $\mathrm{OH}^{-}$hyperalkaline ones control brucite precipitation. The surface runoff has a significant $\mathrm{Mg}$

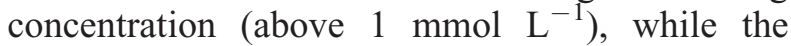
hyperalkaline springs have very low $\mathrm{Mg}$ con-

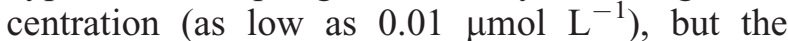
order of magnitude of the hydroxide content at $\mathrm{pH}$ equal to 11 is around $1 \mathrm{mmol} \mathrm{L}^{-1}$ [Chavagnac et al., 2013]. Even if the brucite solubility product $\left(\mathrm{pK}\right.$ of about 11 at $25^{\circ}$ ) is reached at high $\mathrm{pH}$, i.e., brucite is at saturation or supersaturated [Cipolli et al., 2004; Chavagnac et al., 2013], its formation is quantitative only when its components $(\mathrm{Mg}$ and $\mathrm{OH})$ concentrations are of the same order of magnitude, i.e., at moderately alkaline $\mathrm{pH}$ values. This may explain why brucite is always found in the deposit on the wadi beds at a short distance $(<50 \mathrm{~m})$ from the hyperalkaline discharge.

[26] Portlandite was found only once in the mineral deposit covering the bottom of a concrete irrigation channel (falaj) at site 22. Neal and Stanger [1984a] also found this mineral at only one location but along rock surface/joint intersections where the seepage dried out entirely, rather than irrigation channel. In our case, the formation of portlandite results most likely from the alteration of the cement by the high $\mathrm{pH}$ waters, thus leading to high $\mathrm{Ca}$ concentration (above $1 \mathrm{mmol} \mathrm{L}^{-1}$, Chavagnac et al. [2013]). In such context, the high $\mathrm{Ca}$ and $\mathrm{OH}$ activities above portlandite saturation level would induce its precipitation. The numerous piles of white muds digged out by the workers and lying along the full length of the falaj 
indicate that mineral precipitate is problematic in terms of clogging the water channels.

\subsection{Formation of LDHs}

[27] Structurally, LDH minerals are built of two layers of brucite sheets in which $\mathrm{Mg}^{2+}$ is partly substituted by trivalent cations, thus creating a positive charge imbalance that is compensated by various anions in the interlayer space. This is why they are called anionic clays, much less common than cationic clays, e.g., smectite [Riechle, 1986]. The general composition formula is $\left[\mathrm{M}^{2+}{ }_{1-x} \mathrm{M}^{3+}{ }_{x}\right.$ $\left.\left.[\mathrm{OH}]_{2}\right]^{x+}\left[\mathrm{A}^{n-}\right]_{x / n} \cdot m \mathrm{H}_{2} \mathrm{O}\right]$, where $\mathrm{M}^{3+}$ is a trivalent cation such as $\mathrm{Al}^{3+}$ and $\mathrm{Fe}^{3+}$, and $\mathrm{A}^{n-}$ is an anion such as $\mathrm{OH}^{-}, \mathrm{Cl}^{-}, \mathrm{CO}_{3}{ }^{2-}$, and $\mathrm{SO}_{4}{ }^{2-}$ [Allmann, 1968; Miyata, 1975; Cavini et al., 1991]. They exhibit, therefore, a wide range of chemical composition.

[28] Anraku et al. [2009] report the occurrence of $\mathrm{Mg}-\mathrm{Al}$ hydrotalcite-like compounds at two hyperalkaline springs located within the Fizh massif, and one of them corresponds to site 28 of our study. LDH minerals were identified at six localities over the 22 visited sites and are generally associated with brucite (Figure 4). Hydrotalcite occurs with brucite when $x$ has a low value because the high density of $\mathrm{Mg}$ octahedral in the brucite-like sheet acts as nuclei for the formation of brucite [Cavini et al., 1991]. The occurrence of LDHs is observed solely in the vicinity of hyperalkaline springs emerging from the deep-crustal section of the ophiolite, within the bedded gabbro. None has been identified at hyperalkaline springs emerging from the thrust plane. This implies that the rock composition affects the chemistry of the hyperalkaline springs and the secondary mineral precipitation. Based on whole rock chemical composition of Omani ophiolite samples, peridotites contain on average less than 1 wt $\%$ of $\mathrm{Al}_{2} \mathrm{O}_{3}$ [Monnier et al., 2006], whereas gabbros contain around 16-17 wt \% of $\mathrm{Al}_{2} \mathrm{O}_{3}$ [Benoit et al., 1996]. Alteration of gabbroic rocks during meteoric-rock interaction would, therefore, provide a much larger amount of dissolved $\mathrm{Al}^{3+}$ to the solution than peridotites would do, enabling LDHs precipitation. Cationic clays are common minerals formed during water-rock interaction and are found within focused high-temperature sulfur-sulfate hydrothermal chimneys [Wenk and Bulakh, 2006]. This contrasts radically to anionic clays observed in this study. We anticipate that chemical composition of hyperalkaline fluids is of primordial importance in controlling the type of clay being formed. The high-temperature hydrothermal fluid (hydrothermal systems hosted on basaltic to ultrabasic substratum) are characterized by $\mathrm{pH}$ values as low as 2.8 , low Al contents $\left(2-12 \mu \mathrm{mol} \mathrm{L}^{-1}\right)$ but high $\mathrm{SiO}_{2}$ (aq) concentrations $\left(6.9-20 \mathrm{mmol} \mathrm{L}^{-1}\right)$ [Douville et al., 2002]. The Omani hyperalkaline spring waters are characterized by high $\mathrm{pH}$ values (up to 12), low $\mathrm{Al}$ contents (up to $22.8 \mu \mathrm{mol} \mathrm{L}^{-1}$ ) as well as very low $\mathrm{SiO}_{2}(\mathrm{aq})$ concentrations $(<10 \mu \mathrm{mol}$ $\mathrm{L}^{-1}$ ) [Chavagnac et al., 2013]. Even if the hyperalkaline spring waters are mixed by surface runoff waters, the $\mathrm{SiO}_{2}(\mathrm{aq})$ concentration of the solution does not reach the mmol L${ }^{-1}$ range to enable the formation cationic clays made of aluminosilicate layers. But anionic clays made of metal hydroxide layers are favored in such environment.

[29] Indeed, the LDH minerals such as hydrotalcite and indigirite (Tables 1 and 3 ) are concomitant with the occurrence of $\mathrm{Al}^{3+}$ in solution at the main hyperalkaline water discharge (up to 22.8 $\mu \mathrm{mol} \mathrm{L}{ }^{-1}$ ), which drops to zero where the LDH minerals precipitate [Chavagnac et al., 2013]. Iowaite and brugnatellite (Tables 1 and 3 ) are Fe$\mathrm{Mg}$ bearing LDHs that were detected by XRD analyses (Figure 6b). While the inductively coupled plasma-optical emission spectroscopy (ICP-OES) analyses did not permit Fe detection in the hyperalkaline waters at the same localities of our mineralogical analyses [Chavagnac et al., 2013], Paukert et al. [2012] report Fe concentration between 0.04 and $1.74 \mu \mathrm{mol} \mathrm{L}^{-1}$ at several hyperalkaline springs, as the analyses were carried out by inductively coupled plasma-mass spectrometry (ICP-MS) technique. These would sustain our mineralogical observation.

\subsection{Factors Controlling the Aragonite- Calcite Precipitation}

[30] Calcium carbonate minerals are found at all hyperalkaline springs, in association with other minerals, as it is the case for the Oman ophiolite, while being the sole minerals to precipitate at the Voltri Massif. We discuss in the following paragraphs different parameters that may control their precipitation.

\subsubsection{Carbon Origin}

[31] At both localities, the hyperalkaline waters are derived from $\mathrm{CO}_{2}$-rich meteoric waters, whose chemical compositions have been modified via serpentinization reactions. The hyperalkaline waters are characterized by an alkalinity dominated by the hydroxide ion, whereby their DIC has been stripped off and stored at depth [Sader et al., 
2007]. Similar conclusions are obtained on Omani hyperalkaline spring waters [Chavagnac et al., 2013]. This is evidenced by the chemical compositions of emitted gases, which are barren of any carbon dioxide but enriched in hydrogen, nitrogen, and methane [Fritz et al., 1992; Sano et al., 1993; Boulart et al., 2012]. As a result, the calcium carbonate precipitation is dependent either on the $\mathrm{CO}_{2}$ atmospheric uptake or by the DIC supply by surface runoff. In the first case, this is evidenced by the occurrence of a thin calcium carbonate crust at the surface of the hyperalkaline water basins, which do not mix with surface runoff (Figure 5a). The thin surface crust is made of calcite, and on a few cases, aragonite, hydrotalcite, or brucite. During intense pluvial episodes, the thin crust is broken into small pieces and is most likely deposited at the bottom of the wadi. In the second case, the surface runoff waters have a high DIC amount (up to several $\mathrm{mmol} \mathrm{L}^{-1}$ ), and their mixing with the hyperalkaline waters enables the precipitation of calcium carbonate at the wadi bottom. The surface carbonate exhibits $\delta^{13} \mathrm{C}$ values as low as $-27.5 \%$, as a result of strong isotope fractionation during hydroxylation of dissolved atmospheric $\mathrm{CO}_{2}$ [Clark et al., 1992]. In contrast, calcium carbonate found at the wadi bottom (calcite and aragonite) presents a $\delta^{13} \mathrm{C}$ value of $-12.7 \%$ close to that measured in carbonate veins sampled in the ultramafic rocks $(-13.48 \%)$ [Neal and Stanger, 1984a]. According to Clark et al. [1992], this value may indicate that runoff water DIC originates from soil-derived $\mathrm{CO}_{2}$. However, additional $\delta^{13} \mathrm{C}$ analyses of calcium carbonates, forming either at the surface of hyperalkaline spring waters or at the bottom wadi deposit, are necessary to better constrain the origin of the main carbon pool.

\subsubsection{Role of Temperature}

[32] Precipitation of calcium carbonate via experimental work on nonseawater solution indicates that aragonite is the main polymorph to form at temperature above $70^{\circ} \mathrm{C}$, a mixture of aragonite and calcite at temperature comprised between $30^{\circ} \mathrm{C}$ and $60^{\circ} \mathrm{C}$ while calcite is the sole polymorph at temperature below $25^{\circ} \mathrm{C}$ [Kitano, 1962; Folk, 1994]. The Oman and Ligurian hyperalkaline waters are supersaturated with respect to calcite at pH above 10.5 [Chavagnac et al., 2013]. The temperature of the Ligurian springs does not exceed $22^{\circ} \mathrm{C}$, favoring the precipitation of calcite instead of aragonite, in line with our mineralogical analyses (Table 3). The temperature range of the Oman hyperalkaline springs is slightly wider and higher than those of the Voltri Massif, varying from $21^{\circ} \mathrm{C}$

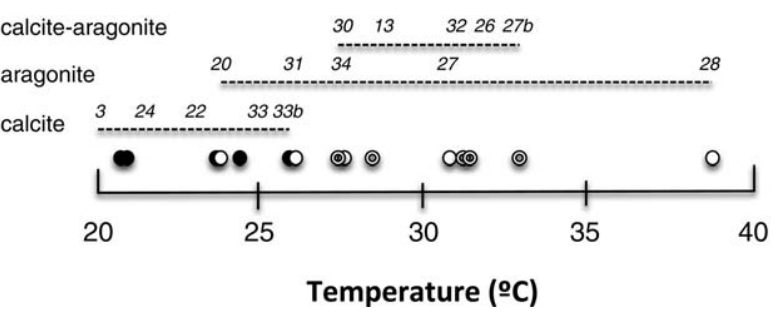

Figure 8. Calcium carbonate polymorph identified versus temperature of the hyperalkaline springs. Italic number indicates the site number.

to $39^{\circ} \mathrm{C}$. Figure 8 illustrates the type of polymorph found according to the measured temperature of the alkaline waters. We conclude that aragonite is the sole polymorph present at temperature above $35^{\circ} \mathrm{C}$ while calcite is favored at temperature lower than $25^{\circ} \mathrm{C}$, and a mixture at intermediate temperature.

\subsubsection{Role of the Chemical Composition of Hyperalkaline Spring Waters}

[33] $\mathrm{Mg}^{2+}, \mathrm{Ca}^{2+}$, and $\mathrm{SO}_{4}{ }^{2-}$ are prevailing ions influencing the type of calcium carbonate polymorph [Reedy et al., 1981; Mucci and Morse, 1983; Folk, 1994; Morse et al., 1997, 2007; Loste et al., 2003; Bots et al., 2011]. A high Mg concentration inhibits the growth of calcite through poisoning of its surface [Lippmann, 1960; Falini et al., 1994]. Sulfate concentration inhibits calcite precipitation over aragonite [Kitano et al., 1975; Busenberg and Plummer, 1987; Walter, 1986], whereby calcite is the sole polymorph to form at low sulfate concentration and $\mathrm{Mg} / \mathrm{Ca}$ ratio close to 0 , while aragonite is the dominant polymorph at high sulfate concentration (above $9 \mathrm{mmol} \mathrm{L}^{-1}$ ) and $\mathrm{Mg} / \mathrm{Ca}$ ratio above 1 [Bots et al., 2011].

[34] In the case of the Ligurian ophiolite, the hyperalkaline springs are characterized by temperatures lower than $25^{\circ} \mathrm{C}$, very low $\mathrm{Mg} / \mathrm{Ca}$ molar ratio, and $\mathrm{SO}_{4}{ }^{2-}$ concentrations in the $\mu \mathrm{mol} \mathrm{L}{ }^{-1}$ range [Chavagnac et al., 2013]. The physicochemical conditions favor the formation of calcite over aragonite, in line with our SEM and XRD analyses (Table 2).

[35] In the case of the Oman ophiolite, calcium carbonates are found in the alkaline springs as either a thin surface crust or wadi bottom deposit. In the first case, the hyperalkaline waters are characterized by the absence of $\mathrm{Mg}$ in solution, very low $\mathrm{Mg} / \mathrm{Ca}$ molar ratio $(<<1)$, and intermediate temperature. As a result, the surface crust is essentially made of calcite, with a mainly intergrown rhombohedral morphology (Figure 5b). At some 
site, rhombohedral calcite crystals are overgrown by needle-like aragonite (Figure $5 \mathrm{c}$ ). In this case, the crystal growth of aragonite is preferentially expressed along the $c$ axis, relative to the other crystallographic directions. In contrast, in the case of the deposit found at the wadi bottom, the hyperalkaline waters have mixed with surface runoff waters, which supply a significant amount of $\mathrm{Mg}$ and sulfate (up to $3 \mathrm{mmol} \mathrm{L}^{-1}$ ) ions to the solution [Stanger, 1986; Weyhenmeyer et al., 2002; Paukert et al., 2012; Chavagnac et al., 2013]. Note, however, that the $\mathrm{Mg}$ concentration of surface runoff is highly variable and ranges between 1.97 and $6.97 \mathrm{mmol} \mathrm{L}^{-1}$ from site to site, while the Ca concentration of most hyperalkaline springs is more constant, close to $2 \mathrm{mmol} \mathrm{L}^{-1}$ [Paukert et al., 2012; Chavagnac et al., 2013]. When the $\mathrm{Mg} / \mathrm{Ca}$ molar ratios are below 2.5, aragonite exhibits several types of morphology either as needle-like shape whereby growth occurs along the $c$ axis (Figure 5c). In contrast, when the $\mathrm{Mg} / \mathrm{Ca}$ molar ratios are above 2.5 , then aragonite exhibits a pyramid shape whereby the plane of the $c$ axis and the plane perpendicular to the $c$ axis are inhibited for crystal growth (Figure 5e). These observations are in line with the laboratory-based experiments [Park et al., 2008].

[36] In the present study, the sulfate concentrations of both surface runoff and hyperalkaline spring waters are well below the $\sim 9 \mathrm{mmol} \mathrm{L}^{-1}$ for observing the impact of sulfate onto the calcite versus aragonite polymorphs [Bots et al., 2011].

\subsubsection{Occurrence of Organic Compounds}

[37] The hyperalkaline springs have a total organic carbon concentration generally around $0.03 \mathrm{mmol}$ $\mathrm{L}^{-1}$ with higher values at sites located at the thrust plane [Chavagnac et al., 2013]. In contrast, the DIC concentrations of continental surface runoff (up to $3.65 \mathrm{mmol} \mathrm{L}^{-1}$ ) are stripped off during serpentinization reactions as the hyperalkaline springs have almost no DIC [Chavagnac et al., 2013]. This implies that surface-catalyzed reduction and polymerization of oxidized single carbon compounds $\left(\mathrm{CO}_{2}, \mathrm{CO}\right.$, and $\left.\mathrm{HCO}_{3}\right)$, referring to the Fischer-Tropsch synthesis (FTS) must have taken place. The abiotic formation of $\mathrm{C}_{1}-\mathrm{C}_{5}$ hydrocarbons and organic acids (such as formic acid, formaldehyde, and methanol intermediaries) is predicted from inorganic precursors under certain hydrothermal conditions [Shock, 1992; Shock and Schulte, 1998; McCollom and Seewald, 2003, 2006; Foustoukos and Seyfried, 2004]. In Oman, gas emissions are essentially composed of hydrogen, nitrogen, methane, and $\mathrm{C}_{2}-\mathrm{C}_{5}$ hydrocarbons at few localities without any $\mathrm{CO}$ and $\mathrm{CO}_{2}[$ Sano et al., 1993; Boulart et al., 2012; Boulart, unpublished data]. The $\mathrm{C}_{1} / \mathrm{C}_{2+}$ ratios, a tool to distinguish microbial (2000-13,000), thermogenic $(<100)$ and abiotic sources [Horita and Berndt, 1999], are generally below 500 (Boulart, unpublished data), falling broadly within the range of experimental FTS results (see the discussion in Proskurowski [2011]). This is supported by the very enriched $\delta^{13} \mathrm{C}$ values $(-12.0$ to $-14.7 \%$ ) for the Oman methane, which argues against a bacterially mediated origin [Fritz et al., 1992]. A possible pathway to produce longer carbon chains, and $\mathrm{H}_{2}$ is the polymerization of $\mathrm{CH}_{4}$ [McCollom and Seewald, 2007].

[38] Humic and fulvic acids, which are commonly found in natural waters, might also be present in solution. However, the arid hydrogeological setting and the absence of soils speak against this. Organic compounds such as exopolymeric substances (EPS) can be produced by microorganisms, and their effect on the calcium carbonate polymorph and morphology will be discussed in the next section.

\subsubsection{Role of Microorganisms}

[39] The term "alkaliphile" is used for microorganisms that require an alkaline $\mathrm{pH}$ above 9 for their growth [Jones et al., 1994]. They are found in high $\mathrm{Ca}-\mathrm{OH}$ groundwaters, such as in Oman, Cyprus, Jordan, and Turkey [Horikoshi, 1999]. In Oman, Satyanarayana et al. [2005] report the occurrence of aerobic bacteria belonging to the genera Bacillus, Vibrio, Pseudomonas, and Flavobacterium. In order to maintain neutral intracellular $\mathrm{pH}$ values in alkaline environments, alkaliphile microorganisms release EPS [Marvasi et al., 2010; Braissant et al., 2007]. In their study of $\mathrm{Ba}$ cillus subtilis, Marvasi et al. [2010] identified four different main functional categories of EPS: structural (neutral polymers: polysaccharides), sorptive (charged polymers: poly- $\gamma$-glutamate), surfaceactive (lipopeptides), and active polymers (proteins). The joint occurrence of Bacillus and EPS in solution may have a strong impact on calcium carbonate polymorph and morphology. For example, Jiao et al. [2006] showed that at high Mg concentrations in solution without addition of collagen (i.e., protein), aragonite precipitates as clusters of crystals typical of needle-like shape. In contrast, the presence of collagen in solution increases the effect of $\mathrm{Mg}$ on the morphology of the $\mathrm{CaCO}_{3}$ polymorphs, whereby aragonite precipitates as dumbbell to spherical crystals. The crystal growth is therefore almost isotropic rather than being 
favored along a preferential axis, leading to the formation of a near spheroidal morphology. In the laboratory-based experiment, Guo et al. [2011] showed that the joint mixture of organic compounds (such as urea) and polymer induces the formation of aragonite as bundles of rods, bouquetlike and dumbbell-like morphologies, playing a crucial role in the oriented aggregation growth. In summary, the different morphologies of calcium carbonate described within these two publications resemble those observed on natural samples (Figures $5 \mathrm{~d}-5 \mathrm{f}$ ), which would suggest that alkaliphile microorganisms are present (but not studied here) and are important parameters in calcium carbonate precipitation.

\subsubsection{Calcium Carbonate Precipitation to Travertine Formation}

[40] In Oman, calcium carbonate accumulation within the wadi river leads to the formation of travertine, which can be up to several meters thick [Clark and Fontes, 1990]. Field descriptions combined within thin-section petrographic observations reveal millimeter-scale layering of travertine. This consolidated but fragile layering may result from the hydrogeological variation through time [Clark and Fontes, 1990]. Clark and Fontes [1990] assessed the paleoclimatic conditions for the past $35 \mathrm{ka}$ for northern Oman based on the isotopic record of $\delta^{13} \mathrm{C}$ and $\delta^{18} \mathrm{O}$ preserved in calcium carbonate associated with hyperalkaline springs. The laminated travertine together with calcium carbonates forming within fractures exhibit $\delta^{13} \mathrm{C}$ and $\delta^{18} \mathrm{O}$ values varying between $-21.9 \%$ and $0 \%$ and $-13.9 \%$ and $+2.7 \%$, respectively. They concluded that the climate has shifted between wet and arid pluvial periods several times over the last $19 \mathrm{ka}$ B.P. in line with the paleoclimatic reconstruction in Saudi Arabia [McClure, 1976]. Moreover, terrestrial paleoclimatic data extracted from terrestrial speleothems provide crucial indicators for the groundwater sources and precipitation intensity to a given area, as seen from their oxygen isotope composition of fluid inclusions [Schwarcz et al., 1976; Kendall and Broughton, 1978]. Based on their geochemical and isotopic study of Omani speleothems, Fleitmann et al. [2003] argue that the groundwater supply over the last $350 \mathrm{ka} \mathrm{B.P.} \mathrm{is}$ driven by southern (Arabian Sea) and northern (Mediterranean frontal system) monsoon precipitations. Furthermore, Rosenberg et al. [2011] suggest that Homo sapiens dispersal in Arabia was favored by monsoon-dominated periods necessary for living but stopped during arid period over the last $125 \mathrm{ka}$ B.P. While these data point to the variability of surface runoff, we cannot conclude whether hyperalkaline spring discharges have fluctuated over time accordingly. Note that major groundwater reservoirs in Oman are either fossils or percolating through the substratum on short time scale (tritium data, Stanger [1986]), suggesting that hyperalkaline waters might be perennial [Clark and Fontes, 1990; Dewandel et al., 2004]. Further analyses such as mineral dating, trace element concentrations, and isotopic compositions $\left(\mathrm{Sr}, \delta^{13} \mathrm{C}\right.$, and $\left.\delta^{18} \mathrm{O}\right)$ profile through the travertine would provide a time frame to assess the origin and intensity of rainfall as well as the hyperalkaline discharge variability.

\subsection{Two Case Examples}

5.5.1. Site 28 "Mamy Nova"

[41] Site 28 is located within the wadi Zabyn running through the Fizh massif. This hyperalkaline spring discharges 1 or $2 \mathrm{~m}$ above the wadi stream through a fracture and is located within the lower crustal section, which is made, at this site, of alternating layers of olivine gabbro and of ultramafic cumulates (pyroxenites and wehrlites) in roughly equal proportions. The intense white precipitates can be observed in the wadi over a length of several hundred meters (Figure 9a). The deposit varies in thickness from place to place as well as in color, suggesting at the same time different mineralogical association and different physico-chemical conditions (Figures 9b-9e). The hyperalkaline waters are characterized by $\mathrm{pH}$ and temperature values of 11.02 and $38.6^{\circ} \mathrm{C}$, respectively, an intense and continuous gas emissions of $\mathrm{H}_{2}, \mathrm{~N}_{2}$, and $\mathrm{CH}_{4}-\mathrm{C}_{2} \mathrm{H}_{6}$, $\mathrm{Mg} / \mathrm{Ca}$ molar ratio equal to 0 (increasing to $\mathrm{Mg} / \mathrm{Ca}$ $>>2.5$ at $\mathrm{pH}$ value $<10.2$ ), low sulfate concentration $\left(<0.2 \mathrm{mmol} \mathrm{L}^{-1}\right)$, and dissolved Al concentration up to $19.4 \mu \mathrm{mol} \mathrm{L} \mathrm{L}^{-1}$ (decreasing to 0 at $\mathrm{pH}<10.2)$ [Chavagnac et al., 2013].

[42] We observe the following mineralogical associations:

(1) Snowball like brucite on top of an aragonite "hedgehog"-like mats turning into a spheroidal morphology (Figure 9b);

(2) A couple of meter away from the discharge area, a more yellowish color typical of aragonite which is present as bundles of rods, or "hedgehog"-like mats, both in association with hydrotalcite (no brucite) (Figure 9c).

(3) At $10 \mathrm{~m}$ away from the discharge, $50 \mathrm{~cm}$ in thickness white deposit, with or without pockmarks, composed of aragonite exhibiting bouquet-like and dumbbell-like morphologies 

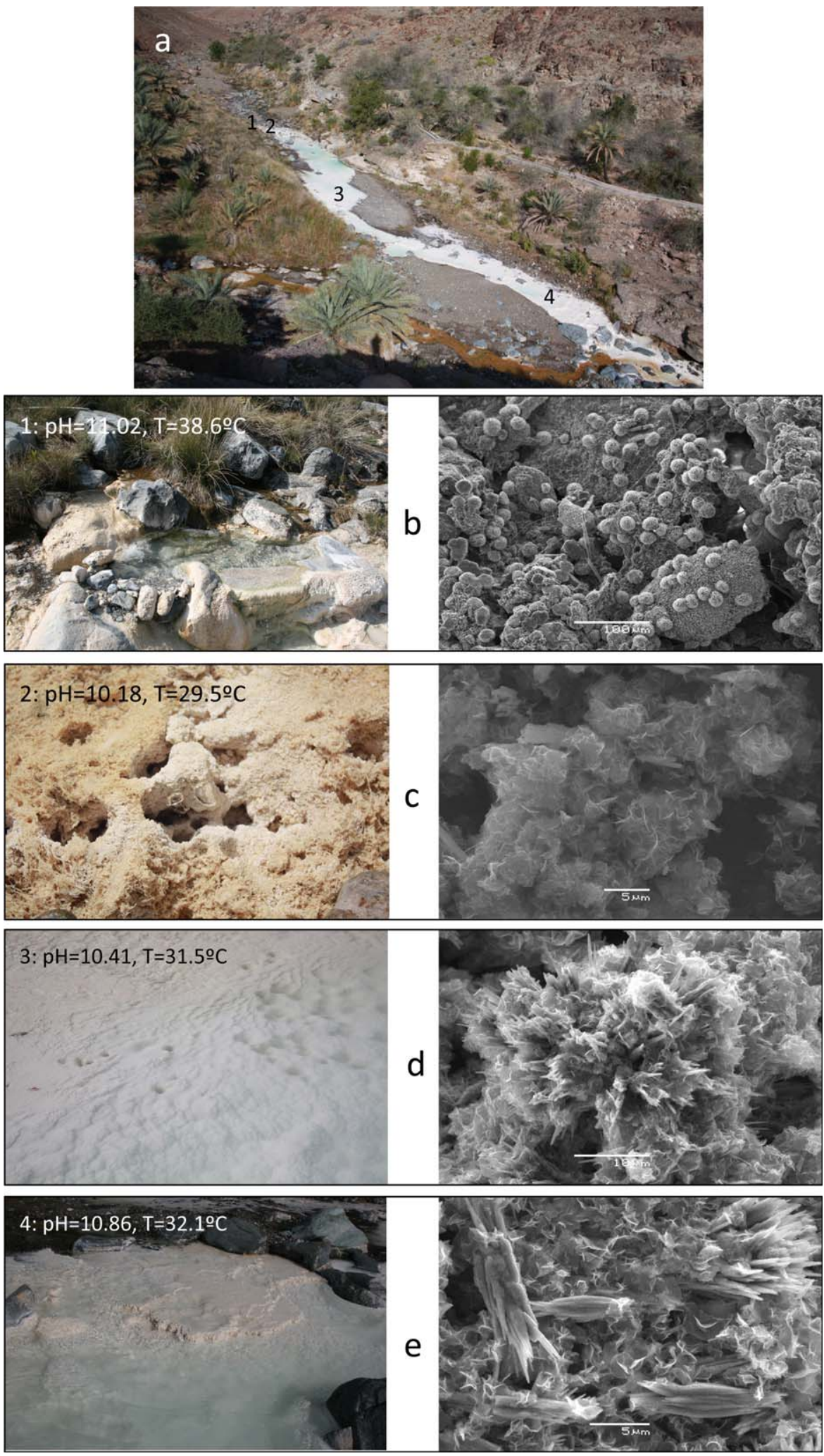

Figure 9. Case example of Site 28 "Mamy Nova": (a) a general view of the site on which numbers refer to following pictures showed in the remaining parts; (b) discharge area of the hyperalkaline spring with SEM images of thin surface crust made of aragonite and brucite; (c) $1 \mathrm{~m}$ away from the discharge area with SEM images of precipitates composed of aragonite and hydrotalcite; (d) thick hydrothermal deposit at the wadi bottom with SEM images of needle- to bouquet-like aragonite together with brucite; (e) thick mineral deposit at the wadi bottom with SEM images of pyramid- to bouquet-like aragonite together with brucite. [Color figure can be viewed in the online issue, which is available at wileyonlinelibrary.com.] 

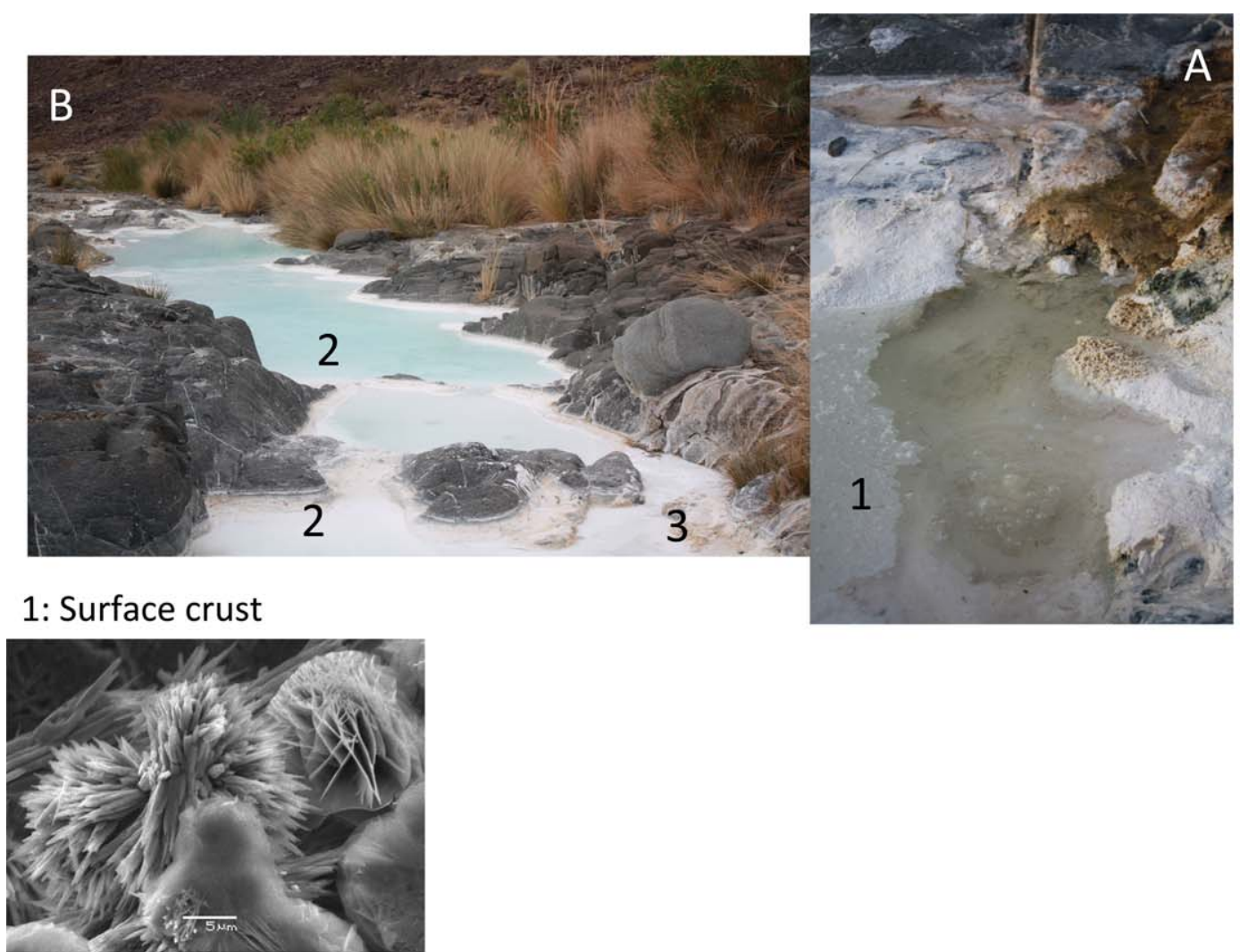

\section{2: Bottom wadi deposit}
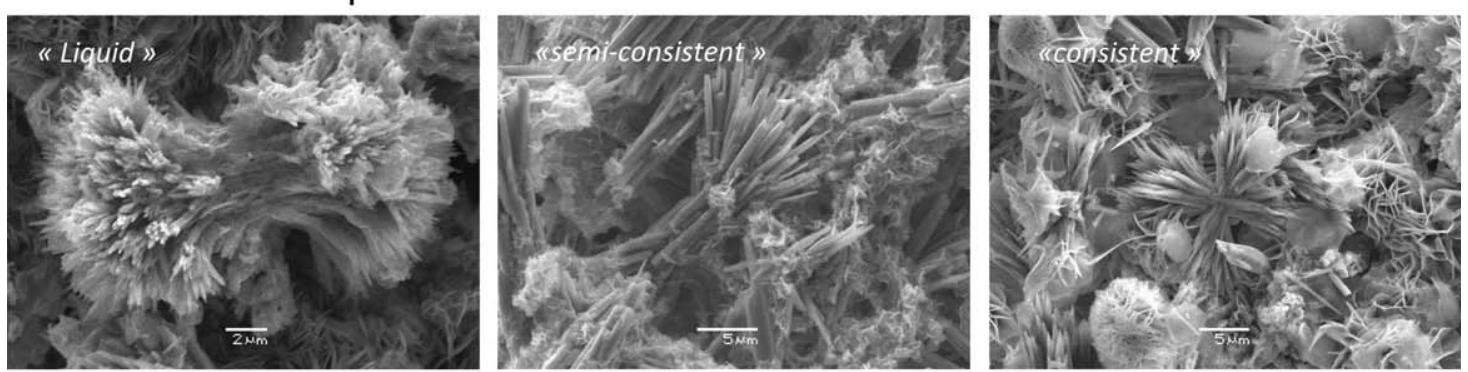

\section{3: Incrustation}

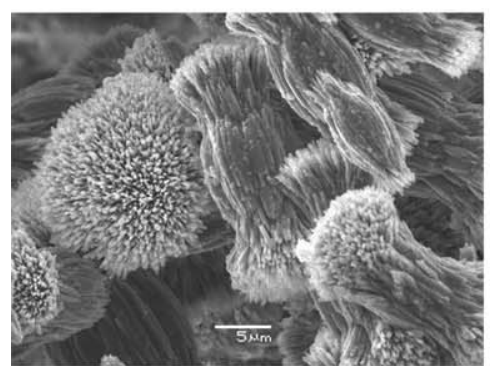

Figure 10. Case example of Site 13 "Gas Pas Chaud": (a) and (b) general view of the site on which numbers indicate specific locations; (1) SEM image of the thin surface crust made of aragonite with a small amount of brucite; (2) SEM images of precipitates found within the "liquid", "semiconsistent" and "consistent" mineral deposit being composed of a few rhombohedral crystals of calcite together with bouquet-like aragonite, needle- to bouquet-like aragonite together with brucite, and bouquet-like aragonite and well-defined snowball-like brucite, respectively. (3) SEM image of bouquet- to spheroidal aragonite. [Color figure can be viewed in the online issue, which is available at wileyonlinelibrary.com.] 


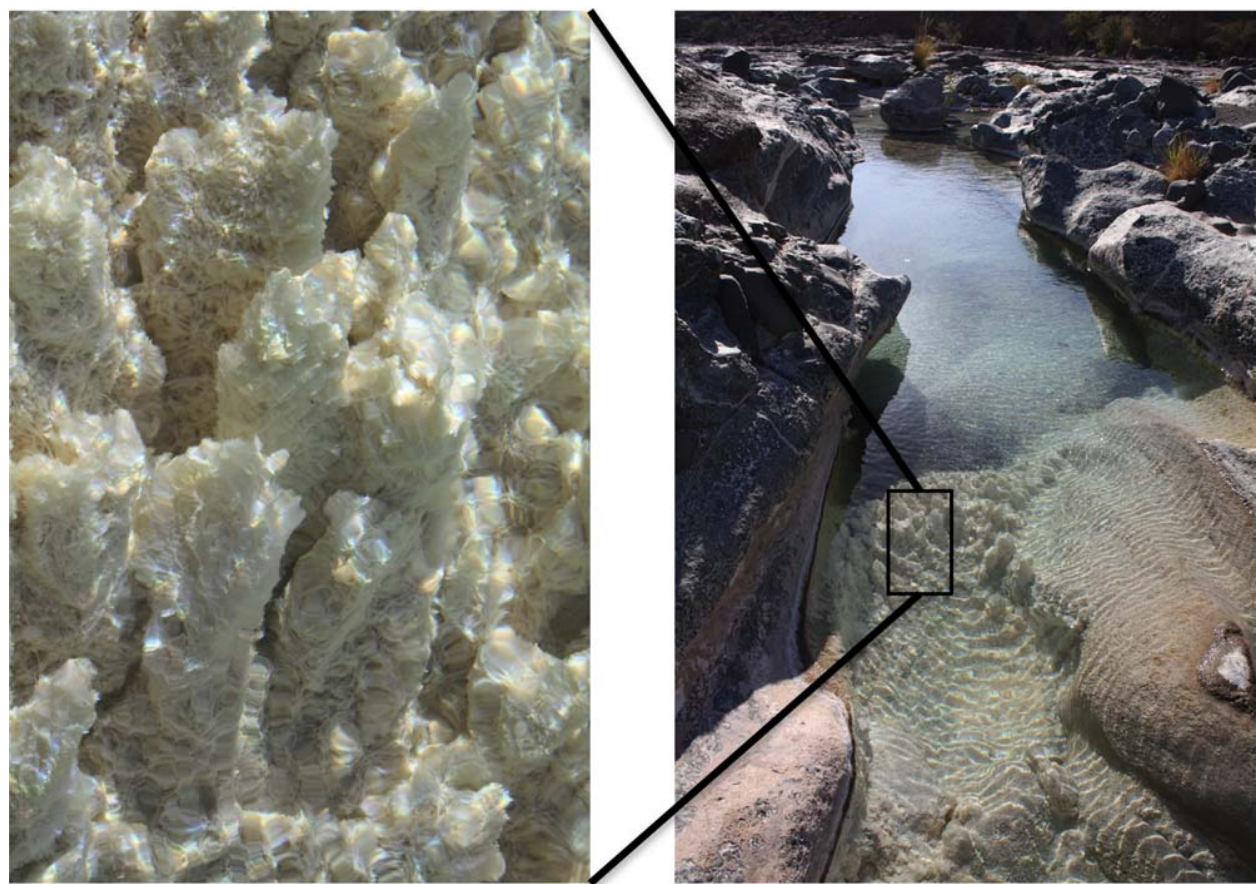

Figure 11. Photographs of Site 13 "Gas Pas Chaud" where $30 \mathrm{~cm}$ tall calcium carbonate chimneys are observed within the wadi. [Color figure can be viewed in the online issue, which is available at wileyonlinelibrary.com.]

together with snowball like brucite (no hydrotalcite) (Figures 9d and 9e).

[43] The mineralogical assemblages seem to be essentially controlled by (1) the temperature (aragonite over calcite), (2) the chemical composition of the hyperalkaline waters $(\mathrm{Mg} / \mathrm{Ca}$ molar ratios and $\mathrm{Al}$ concentrations) onto calcium carbonate polymorphs and brucite versus LDH minerals, and potentially by (3) the occurrence of organic compounds (polymer) linked with alkaliphile microorganisms to sustain the spheroidal-like morphology of aragonite. But the latter remains to be proven.

\subsubsection{Site 13 "Gas Pas Chaud"}

[44] This site is located within the Wuqbah massif in the mantle peridotites (harzburgites and dunites) just below the transition with the overlying crustal gabbroic cumulates. The hyperalkaline spring discharges directly into the wadi, which flows slowly between the hill slopes (Figures 10a and 10b). The hyperalkaline waters are characterized by a $\mathrm{pH}$ and temperature value of 11.7 and $28.4^{\circ} \mathrm{C}$, respectively, depleted in $\mathrm{Mg}$ and $\mathrm{Al}$, and gas bubbles made of $\mathrm{H}_{2}, \mathrm{~N}_{2}, \mathrm{CH}_{4}$, and $\mathrm{C}_{2}-\mathrm{C}_{5}$ hydrocarbons [Chavagnac et al., 2013; Boulart et al., 2012; Boulart, unpublished data]. As the water flow is sluggish, a thin surface crust is present at the discharge area (Figures 10a and 10c).
[45] We observe the following mineralogical associations:

(1) Aragonite exhibiting bouquet-like morphology together with small amounts of rhombohedral calcite and snowball like brucite at the thin surface crust (Figure 10c).

(2) Aragonite exhibits needle-, bouquet-, and dumbbell-like morphology together with brucite according to the degree of consolidation of the mineral deposit (Figures 10d and 10e).

(3) The occurrence delicate chimneys, which are transformed into a very fluid suspension as soon as we tried to sample them (Figure 11). The mineralogy is undetermined.

[46] We conclude that the following parameters control the mineralogical association: (1) intermediate temperature onto the calcium carbonate polymorph, (2) the chemical composition of hyperalkaline springs linked to the alteration of peridotite onto brucite occurrence rather than $\mathrm{LDH}$ minerals, (3) the carbon origin $\left(\mathrm{C}_{1}-\mathrm{C}_{5}\right)$ probably associated with organic compounds onto the morphologies of calcium carbonate, and (4) the potential existence of polymer (which is not yet proven) onto the aragonite morphologies in line with synthesis experiments of Guo et al. [2011]. 


\section{Conclusions}

[47] The percolation of meteoric water through fractures within the ultramafic rocks of the Liguria and Oman ophiolites leads to the formation of hyperalkaline springs via the serpentinization reactions at depth. The hyperalkaline springs and their precipitates are ubiquitous and numerous over the entire ophiolite belts at both locations, but display different modes of occurrence and morphologies as evidenced by our XRD and SEM analyses.

[48] We conclude that:

[49] (1) In Oman, precipitates linked to hyperalkaline springs occur either as a thin crust at the surface of isolated and still basin or as unstructured to structured white-orange deposit within the wadi bed, while in Liguria, a thin calcium carbonate deposit on the bedrock is observed.

[50] (2) In Liguria, it is the simultaneous atmospheric $\mathrm{CO}_{2}$ uptake and neutralization of the hyperalkaline waters, which lead to the precipitation of calcium carbonate. The precipitates are made of calcite, and no $\mathrm{Mg} / \mathrm{Ca}$ hydroxide minerals are found.

[51] (3) Three main minerals have been identified in Oman precipitates: calcium carbonates, $\mathrm{Mg}$ and $\mathrm{Ca}$ hydroxides (brucite and portlandite), and hydrated hydroxides (LDHs).

[52] (4) In Oman, brucite is commonly observed both at hyperalkaline springs located at the thrust plane and at the paleo-Moho. The varying mixing proportions between the $\mathrm{Mg}-\mathrm{HCO}_{3}{ }^{-}$surface runoff waters and the $\mathrm{Ca}-\mathrm{OH}^{-}$hyperalkaline ones control brucite precipitation.

[53] (5) In Oman, the LDH minerals occur solely in vicinity of hyperalkaline springs emerging from deep-crustal section of the ophiolite, within the bedded gabbro, implying the strong control of rock composition on the chemistry of the hyperalkaline springs and on the secondary mineral precipitation.

[54] (6) It is the concomitant reactions of $\mathrm{CO}_{2}$ atmospheric uptake and neutralization of alkaline waters, which lead to the formation of calcium carbonate minerals. This process is observed as a thin surface crust made of calcium carbonate polymorph-rhombohedral calcite at most sites, associated at some places with snowball-like brucite. The calcium carbonate polymorph varies within the bottom wadi deposit but is generally calcite at sluggish flow of water discharge while being aragonite in more dynamic hydrogeological environment. Morphological features of aragonite vary from needle-, bouquet-, dumbbell-, spheroidal-like habitus according to the origin of carbon, tempera- ture, and ionic composition of the hyperalkaline springs, and the biochemical and organic compounds.

[55] (7) Finally, the dominant mineralogical associations we found in Oman (Ca-bearing carbonates and brucite) in a serpentinizing environment driven by the meteoric waters are surprisingly the same as those observed at the Lost City hydrothermal site in a totally marine environment.

\section{Acknowledgments}

[56] Funding for this study was provided by INSU-CNRS CESSUR program in 2009 and 2010. The authors thank Michel Thibaut, Thierrry Aigouy, and Sophie Gouy for their technical support during the course of the mineralogical analyses. We acknowledge constructive comments of two anonymous reviewers.

\section{References}

Abily, B., G. Ceuleneer, and P. Launeau (2011), Syn-magmatic normal faulting in the lower oceanic crust: Evidence from the Oman ophiolite, Geology, 39, 391-394.

Alabaster, T., J. A. Pearce, and J. Malpas (1982), The volcanic stratigraphy and petrogenesis of the Oman Ophiolite complex, Contrib. Mineral. Petrol., 81, 168-183.

Allmann, R. (1968), The crystal structure of pyroaurite, Acta Crystallogr., B, 24, 972-977.

Anraku, S., K. Morimoto, T. Sato, and T. Yoneda (2009), Formation of secondary minerals and uptake of various anions under naturally-occurring hyperalkaline conditions in Oman, in Proceedings of the 12th International Conference on Environmental Remediation and Radioactive Waste Management, 11-15 October, Liverpool, UK, Vol. 2, 849-854, Am. Soc. Mech. Eng., New York.

Alt, J. C. (1995), Sulfur isotopic profile through the oceaniccrust: Sulfur mobility and seawater-crustal sulfur exchange during hydrothermal alteration, Geology, 27, 585-588.

Bach, W., H. Paulick, C. J. Garrido, B. Ildefonse, W. P. Meurer, and S. E. Humphris (2006), Unraveling the sequence of serpentinization reactions: Petrography, mineral chemistry, and petrophysics of serpentinites from MAR $15^{\circ} \mathrm{N}$ (ODP Leg 209, Site 1274), Geophys. Res. Lett., 33, L13306, doi:10.1029/2006GL025681.

Benoit, M., M. Polvé, and G. Ceuleneer (1996), Trace element and isotopic composition of mafic cumulates in a fossil mentle diapir (Oman ophiolite), Chem. Geol., 134, 199-214.

Benoit, M., G. Ceuleneer, and M. Polvé (1999), The remelting of hydrothermally altered peridotite at mid-ocean ridges by intruding mantle diapirs, Nature, 402, 514-518.

Bots, P., L. G. Benning, R. E. M. Rickaby, and S. Shaw (2011), The role of SO4 in the switch from calcite to aragonite seas, Geology, 39(4), 331-334.

Boulart, C., V. Chavagnac, A. Delacour, C. Monnin, G. Ceuleneer, and G. Hoareau (2012), New insights into gas compositions from hyperalkaline springs in Oman, Italy (Liguria) and New Caledonia (Prony Bay), paper presented at Serpentines 2012 Workshop, 2-6 September 2012, Porquerolles, France. 
Braissant, O., A. W. Decho, C. Dupraz, C. Glunk, K. M. Przekop, and P. T. Visscher (2007), Exopolymeric substances of sulfate-reducing bacteria: Interactions with calcium at alkaline $\mathrm{pH}$ and implication for formation of carbonate minerals, Geobiology, 5, 1-11, doi:10.1111/j.1472-4669.2007.00117.

Brouwer, F. M., R. L. M. Vissers, and W. M. Lamb (2002), Metamorphic history of eclogitic metagabbro blocks from a tectonic melange in the Voltri Massif, Ligurian Alps, Italy, Ofioliti, 27(1), 1-16.

Busenberg, E., and N. Plummer (1987), A comparative study of the dissolution and crystal growth kinetics of calcite and aragonite, U.S. Geol. Surv. Bull., 1578, 139-168.

Cavini, F., F. Trifirò, and A. Vaccari (1991), Hydrotalcite-type anionic clays: Preparation, properties and applications, Catal. Today, 11, 173-301.

Chavagnac, V., C. Monnin, G. Ceuleneer, C. Boulart, and G. Hoareau (2013), Characterization of hyperalkaline fluids produced by low temperature serpentinization of mantle peridotites in the Sultanate of Oman and in Liguria (Northern Italy), Geochem. Geophys. Geosyst., in press..

Ceuleneer, G., M. Monnereau, and I. Amri (1996), Thermal structure of a fossil mantle diapir inferred from the distribution of mafic cumulates, Nature, 379, 149-153.

Cipolli, F., B. Gambardella, L. Marini, G. Ottonello, and M. Vetuschi Zuccolini (2004), Geochemistry of high-pH waters from serpentinites of the Gruppo di Voltri (Genova, Italy) and reaction path modeling of $\mathrm{CO} 2$ sequestration in serpentinite aquifers, Appl. Geochem., 19(5), 787-802.

Clark, I. D., and J.-C. Fontes (1990), Paleoclimatic reconstruction in Northern Oman based on carbonates from hyperalkaline groundwaters, Quat. Res., 33, 320-336.

Clark, I. D., J.-C. Fontes, and P. Fritz (1992), Stable isotope disequilibria in travertine from high $\mathrm{pH}$ waters: Laboratory investigations and field observations from Oman, Geochim. Cosmochim. Acta, 56, 2041-2050.

Clénet, H., G. Ceuleneer, P. Pinet, B. Abily, Y. Daydou, E. Harris, I. Amri, and C. Dantas (2010), Thick sections of layered ultramafic cumulates in the Oman ophiolite revealed by an airborne hyperspectral survey: Petrogenesis and relationship to mantle diapirism, Lithos, 114, 265-281, doi:10.1016/j.lithos.2009.09.002.

Coleman, R. G. (1981), Tectonic setting for ophiolite obduction in Oman, J. Geophys. Res., 86, 2497-2508.

Combe, J.-P., P. Launeau, P. Pinet, D. Despan, E. Harris, G. Ceuleneer, and C. Sotin (2006), Mapping of an ophiolite complex by high-resolution visible-infrared spectrometry, Geochem. Geophys. Geosyst., 7, Q08001, doi:10.1029/2005GC001214.

Dewandel, B., P. Lachassagne, and A. Qatan (2004), Spatial measurements of steam baseflow, a relevant method for aquifer characterization and permeability evaluation. Application to a hard-rock aquifer, the Oman ophiolite, Hydrol. Processes, 18, 3391-3400.

Douville, E., J. L. Charlou, E. H. Oelkers, P. Bienvenu, C. F. Jove Colon, J. P. Donval, Y. Fouquet, D. Prieur, and P. Apprious (2002), The rainbow vent fluids ( $\left.36^{\circ} 14^{\prime} \mathrm{N}, \mathrm{MAR}\right)$ : The influence of ultramafic rocks and phase separation on trace metals content in Mid-Atlantic Ridge hydrothermal fluids, Chem. Geol., 184, 37-48.

Falini, G., M. Gazzano, and A. Ripamonti (1994), Crystallisation of calcium carbonate in presence of magnesium and polyelectrolytes, J. Cryst. Growth, 137(3-4), 577-584.

Fleitmann, D., S. J. Burns, U. Neff, A. Mangini, and A. Matter (2003), Changing moisture sources over the last 330,000 years in Northern Oman from fluid-inclusion evidence in speleothems, Quat. Res., 60, 223-232.
Folk, R. L. (1994), Interaction between bacteria, nannobacteria, and mineral precipitation in hot springs of central Italy, Géogr. Phys. Quat., 48(3), 233-246.

Ford, T. D., and H. M. Pedley (1996), A review of tufa and travertines deposits of the world, Earth Sci. Rev., 41, 117-175.

Fouke, B. W., J. D. Farmer, D. J. Des Marais, L. Pratt, N. C. Sturchio, P. C. Burns, and M. K. Discipulo (2000), Depositional facies and aqueous-solid geochemistry of travertinsdepositing hot springs (Angel terrace, Mammoth hot springs, Yellowstone National Park, U.S.A.), J. Sediment. Res., $70(3), 565-585$.

Fournier, M., C. Lepvrier, P. Razin, and L. Jolivet (2006), Post-obduction extension in the Oman mountains and subsequent compression, GeoArabia, 4, 17-40.

Foustoukos, D. I., and W. E. Seyfried (2004), Hydrocarbons in hydrothermal fluids: The role of chromium-bearing catalysts, Science, 304, 1002-1005.

France, L., B. Ildefonse, and J. Koepke (2009), Interactions between magma and hydrothermal system in Oman ophiolite and in IODP Hole 1256D: Fossilization of a dynamic melt lens at fast spreading ridges, Geochem. Geophys. Geosyst., 10, Q10019, doi:10.1029/2009GC002652.

Fritz, P., I. D. Clark, J.-C. Fontes, M. J. Whiticar, and E. Faber (1992), Deuterium and ${ }^{13} \mathrm{C}$ evidence for low temperature production of hydrogen and methane in a highly alkaline groundwater environment in Oman, paper presented at 7th International Symposium on Water-Rock Interaction, 13-18 July 1992, pp. 793-796, Rotterdam, Netherlands. Park City, Utah.

Ghent, E. D., and M. Z. Stout (1981), Metamorphism at the base of the Samail ophiolite, Southeastern Oman Mountains, J. Geophys. Res., 86, 2557-2571.

Glennie, K. W., M. G. A. Boeuf, M. W. Hughes-Clark, M. Moody-Stuart, W. F. H. Pilaar, and B. M. Reinhardt (1974), Geology of the Oman Mountains, Verh. K. Ned. Geol. Mijnboukd. Genoot., 31, 423.

Gregory, R. T., and H. P. Taylor (1981), An oxygen isotope profile in a section of cretaceous oceanic crust, Samail ophiolite, Oman: Evidence for $\delta 180$ buffering of the oceans by deep $(>5 \mathrm{~km})$ seawater-hydrothermal circulation at midocean ridges, J. Geophys. Res., 86, 2737-2755.

Guillaume, D., A. Neaman, M. Cathelineau, R. Mosser-Ruck, C. Peiffert, M. Abdelmoula, J. Dubessy, F. Villiéras, and N. Michau (2004), Experimental study of the transformation of smectite at $80^{\circ} \mathrm{C}$ and $300^{\circ} \mathrm{C}$ in the presence of iron oxides, Clay Miner., 39, 17-34.

Guo, H., Z. Qin, P. Qian, P. Yu, S. Cui, and W. Wang (2011), Crystallization of aragonite $\mathrm{CaCO}_{3}$ with complex structures, Adv. Powder Technol., 22, 777-783, doi:10.1016/ j.apt.2010.11.04.

Halbach, P. E., Y. Fouquet, and P. Herzig (2003), Mineralization and Compositional Patterns in Deep-Sea Hydrothermal Systems, in Energy and Mass Transfer in Marine Hydrothermal Systems, edited by P. Halbach, V. Tunnicliffe, and J. R. Hein, Dalhem Univ. Press, Berlin.

Hermann, J., O. Müntener, and M. Scambelluri (2000), The importance of serpentinite mylonites for subduction and exhumation of oceanic crust, Tectonophysics, 327, 225-238.

Ho, K.-S., J.-C. Chen, C.-H. You, S.-C. Hsu, and M.-H. Huang (2009), The first occurrence of suolunite in Taiwan: Its physical properties, chemical composition, and genesis, Coll. Res., 22, 1-13.

Hoogerduijn Strating, E. H., E. Rampone, G. B. Piccardo, M. R. Drury, and R. L. M. Vissers (1993), Subsolidus emplacement of mantle peridotites during incipient oceanic rifting 
and opening of the Mesozoic Tethys (Voltri massif, NW Italy), J. Petrol., 34, 901-927.

Horikoshi, K. (1999), Alkaliphiles: Somes applications of their products for biotechnology, Microbiol. Mol. Bio. Rev., 63(4), 735-750.

Horita, J., and M. E. Berndt (1999), Abiogenic methane formatio and isotopic fractionation under hydrothermal conditions, Science, 285(5430), 1055-1057.

Huang, Y. (1965), Suolunite : A new mineral [in Chinese], Geol. Rev., 23(1), 7.

Jiao, Y., Q. Feng, and X. Li (2006), The co-effect of collagen and magnesium ions on clacium carbonate biomineralozation, Mater. Sci. Eng. C, 26, 648-652.

Jones, B. E., W. D. Grant, N. C. Collins, and W. E. Mwatha (1994), Alkaliphiles: Diversity and identification, in Bacterial Diversity and Systematics, edited by F. G. Priest, pp. 195-230, Plenum, New York.

Juteau, T., M. Ernewein, I. Reuber, H. Whitechurch, and R. Dahl (1988), Duality of magmatism in the plutonic sequence of the Semail Nappe, Oman, Tectonophysics, $151,107-126$.

Juteau, T., G. Manac'h, O. Moreau, C. Lécuyer, and C. Ramboz (2000), The high temperature reaction zone of the Oman ophiolite: New field data, microthermometry of fluid inclusions, PIXE analyses and oxygen isotopic ratios, Mar. Geophys. Res., 21, 351-385.

Kelemen, P. B., and J. Matter (2008), In situ carbonation of peridotite for $\mathrm{CO}_{2}$ storage, Proc. Natl. Acad. of Sci. U. S. A., 105(45), 17,295-17,300.

Kelley, D. S., et al. (2001), An off-axis hydrothermal vent field near the Mid-Atlantic Ridge at $30^{\circ} \mathrm{N}$, Nature, 412, 145-149.

Kelley, D. S., et al. (2005), A Serpentinite-hosted ecosystem: The Lost City hydrothermal field, Science, 307, 1428-1434.

Kendall, A. C., and P. L. Broughton (1978), Origin of fabrics in Speleothems composed of columnar calcite crystals, $J$. Sediment. Petrol., 48, 519-538.

Kitano, Y. (1962), The behavior of various inorganic ions in the separation of calcium carbonate from a bicarbonate solution, Bull. Chem. Soc. Jpn., 35, 1973-1980.

Kitano, Y., M. Okumura, and M. Idogaki (1975), Incorporation of sodium, chloride and sulfate with calcium carbonate, Geochem. J., 9, 75-84.

Köster, H. M. (1995), Die röntgenographische identifizierung der silikatischen Tonminerale und beigemengter Akzessorien in Texturpräparaten, Z. Geol. Wissenschaften, 23, 287300.

Lachize, M., J.-P. Lorand, and T. Juteau (1996), Calc-alkaline differentiation trend in the plutonic sequence of the Wadi Haymiliyah section, Haylayn massif, Semail ophiolite, Oman, Lithos, 38, 207-232.

Launay, J. (1981), Les sources thermales de Prony, La Nouvelle Caledonie essai de J.P. Paris, BRGM, pp. 113.

Launay, J., and J.-C. Fontes (1985), Les sources thermales de Prony [Nouvelle Calédonie] et leurs précipités chimiques. Exemple de formation de brucite primaire, Géol. France, 1, 83-100.

Leblanc, M., G. Ceuleneer, H. Al Azri, and J. Jedwab (1991), Concentration hydrothermale de $\mathrm{Pd}$ et de Pt dans les péridotites mantellaires du complexe ophiolitique d'Oman, C. R. Acad. Sci., 312(2), 1007-1012.

Lippmann, F. (1960), Versuche zur Auf klarung der Bildungsbedin- gungen von Calcit und Aragonit, Fortschr. Mineral., $38,156-161$.

Loste, E., R. M. Wilson, R. Seshadri, and F. C. Meldrum (2003), The role of magnesium in stabilising amorphous cal- cium carbonate and controlling calcite morphologies, $J$. Cryst. Growth, 254, 206-218.

Ludwig, K. A., D. S. Kelley, D. A. Butterfield, B. K. Nelson, and G. Früh-Green (2006), Formation and evolution of carbonate chimneys at the Lost City Hydrothermal Field, Geochim. Cosmochim. Acta, 70, 3625-3645.

Marini, L., and G. Ottonello (2002), Atlante degli acquiferi della Liguria, vol. 3, Le acque dei complessi ofiolitici (bacini: Arrestra, Branega, Cassinelle, Cerusa, Erro, Gorzente, Leira, Lemme, Lerone, Orba, Piota, Polcevera, Rumaro, Sansobbia, Stura, Teiro, Varenna, Visone), Univ. degli Studi di Genova, Pacini, Pisa, Italy.

Marvasi, M., P. T. Visscher, and L. Casillas-Martinez (2010), Exopolymeric substances (EPS): From Bacillus subtilis: Polymers and genes encoding their synthesis, FEMS Microbiol. Lett., 1-9, doi:10.1111/j.15746968.2010.02085.

Matter, J. M., and P. B. Kelemen (2009), Permanent storage of carbon dioxide in geological reservoirs by mineral carbonation, Nature Geosci., 2(12), 837-841.

Mével, C. (2003), Serpentinization of abyssal peridotites at mid-ocean ridges, C. R. Acad. Sci., 335, 825-852.

McClure, H. A. (1976), Radiocarbon chronology of Late Quatemary lakes in the Arabian Peninsula, Nature, 263, 755756.

McCollom, T. M., and J. S. Seewald (2003), Experimental study of the hydrothermal reactivity of organic acids and acid anions: I. Formic acid and formate, Geochim. Cosmochim. Acta, 67(19), 3625-3644.

McCollom, T. M., and J. S. Seewald (2006), Carbon isotope composition of organic compounds produced by abiotic synthesis under hydrothermal conditions, Earth Planet. Sci. Lett., 243, 74-84.

McCollom, T. M., and J. S. Seewald (2007), Abiotic syntheis of organic coumpounds in deep-sea hydrothermal environments, Chem. Rev., 107, 382-401.

Monnier, C., J. Girardeau, L. Le Mée, and M. Polvé (2006), Along-ridge petrological segmentation of the mantle in the Oman ophiolite. Geochem, Geophys. Geosyst., 7, Q11008, doi:10.1029/2006GC001320.

Morse, J. W., Q. Wang, and M. Y. Tsio (1997), Influences of temperature and $\mathrm{Mg}: \mathrm{Ca}$ ratio on $\mathrm{CaCO} 3$ precipitates from seawater, Geology, 25(1), 85-87.

Morse, J. W., R. S. Arvidson, and A. Luttge (2007), Calcium carbonate formation and dissolution, Chem. Rev., 107, 342381.

Mucci, A., and J. W. Morse (1983), The incorporation of $\mathrm{Mg} 2+$ and $\mathrm{Sr} 2+$ into calcite overgrowths: Influences of growth rate and solution composition, Geochim. Cosmochim. Acta., 47(2), 217-233.

Miyata, S. (1975), The syntheses of hydrotalcite-like compounds and their structures and physico-chemical properties: The systems $\mathrm{Mg} 2+-\mathrm{Al} 3+-\mathrm{NO} 3-, \mathrm{Mg} 2+-\mathrm{A} 13+-\mathrm{Cl}-$, $\mathrm{Mg} 2+-\mathrm{Al} 3+-\mathrm{ClO} 4-, \mathrm{Ni} 2+-\mathrm{Al} 3+-\mathrm{Cl}-$, and $\mathrm{Zn} 2+-$ Al3+- Cl-, Clays Clay Miner., 23, 369-375.

Neal, C., and G. Stanger (1983), Hydrogen generation from mantle source rocks in Oman, Earth Planet. Sci. Lett., 66, 315-320.

Neal, C., and G. Stanger (1984a), Calcium and magnesium-hydroxide precipitation from alkaline groundwaters in Oman, and their significance to the process of serpentinization, Mineral. Mag., 48(347), 237-241.

Neal, C., and G. Stanger (1984b), Past and present serpentinization of ultramafic rocks: An example from the Semail ophiolite nappe of Northern Oman, in Proceedings of the 
NATO Advanced Research Workshop on the Chemistry of Weathering, edited by T. Drever, pp. 249-275, D. Reidel, Dordrecht, Netherlands.

Nehlig, P. (1993), Interactions between magma chambers and hydrothermal systems: Oceanic and ophiolitic constraints, $J$. Geophys. Res., 98, 19,621-19,633.

Pallister, J. S. (1981), Structure of the sheeted dyke complex of the Samail ophiolite near Ibra, Oman, J. Geophys. Res., $86,2661-2672$.

Pallister, J. S., and C. A. Hopson (1981), Samail ophiolite plutonic suite: Field relations, phase variations, cryptic variation and layering, and a model of a spreading Ridge magma chamber, J. Geophys. Res., 86, 2593-2644.

Park, W. K., S.-J. Ko, S. W. Lee, K.-H. Cho, J.-W. Ahn, and C. Han (2008), Effects of magnesium chloride and organic additives on the synthesis of aragonite precipitated calcium carbonate, J. Cryst. Growth, 310, 2593-2601.

Paukert, A. N., J. M. Matter, P. B. Kelemen, E. L. Schock, and J. R. Havig (2012), Reaction path modeling of enhanced in situ CO2 mineralization for carbon sequestration in the peridotite of the Samail Ophiolite, Sultanate of Oman, Chem. Geol., 330-331, 86-100.

Pearce, J. A., T. Alabaster, A. W. Shelton, and M. P. Searle (1981), The Oman ophiolite as a cretaceous arc-basin complex: Evidence and implications, Philos. Trans. R. Soc. London, 300, 299-317.

Pentecost, A. (1995), Quaternary travertine deposits of Europe and Asia Minor, Quat. Sci. Rev., 14, 1005-1028.

Proskurowski, G., M. D. Lilley, J. S., Seewald, G. Früh-Green, E. J. Olson, J. E. Lupton, S. P. Sylva, and D. S. Kelley (2008), Abiogenic hydrocarbon production at Lost City hydrothermal field, Science, 319(5863), 604-607.

Proskurowski, G. (2011), Abiogenic hydrocarbon production at the geosphere- biosphere interface via Serpentinization reactions, in Handbook of Hydrocarbon and Lipid Microbiology, vol. 14, edited by K. N. Timmis, 215-231, Springer, Berlin.

Python, M., and G. Ceuleneer (2003), Nature and distribution of dykes and related melt migration structures in the mantle section of the Oman ophiolite, Geochem. Geophys. Geosyst., 4(7), 8612, doi:10.1029/2002 GC000354.

Python, M., G. Ceuleneer, Y. Ishida, J.-A. Barrat, and S. Arai (2007), Oman diopsidites: A new lithology diagnostic of very high temperature hydrothermal circulation in mantle peridotite below oceanic spreading centres, Earth Planet. Sci. Lett., 255, 289-305.

Reedy, M. M., L. N. Plummer, and E. Busenberg (1981), Crystal growth of calcite from calcium bicarbonate solutions at constant $\mathrm{PCO} 2$ and $25^{\circ} \mathrm{C}$ : A test of a calcite dissolution model, Geochim. Cosmochim. Acta, 45(8), 1281-1289.

Renaut, R. W., and B. Jones (1997), Controls on aragonite and calcite precipitation in hot spring travertines at Chemurkeu, Lake Bogoria, Kenya, Can. J. Earth Sci., 34, 801-818.

Renaut, R. W., B. Jones, and C. Le Turdu (1999), Calcite lilypads and ledges at Lorusio Hot Springs, Kenya Rift Valley: Travertine precipitation at the air-water interface, Can. J. Earth Sci., 36, 649-666.

Renaut, R. W., B. Jones, J.-J. Tiercelin, and C. Tarits (2002), Sublacustrine precipitation of hydrothermal silica in rift lakes: Evidence from Lake Baringo, central Kenya Rift Valley, Sediment. Geol., 148, 235-257.

Riechle, W. T. (1986), Synthesis of anionic clay minerals (mixed metal hydroxides, hydrotalcite), Solid States Ionics, $22,135-141$.
Rosenberg, T. M., F. Preusser, D. Fleitmann, A. Schwalb, K. Penkman, T. W. Schmid, M. A. Al-Shanti, K. Kadi, and A. Matter (2011), Humid periods in southern Arabia: Windows of opportunity for modern human dispersal, Geology, 39, 1115-1118.

Sader, J. A., M. I. Leybourne, B. McClenaghan, and M. S. Hamilton (2007), Low-temperature serpentinization processes and kimberlite groundwater signatures in the Kirkland Lake and Lake Timiskiming kimberlite fields, Ontario, Canada: Implications for diamond exploration, Geochemistry, 7, $3-21$.

Sano, Y., A. Urabe, and H. Wakita (1993), Origin of hydrogen-nitrogen gas seeps, Oman, Appl. Geochem., 8, 1-8.

Satyanarayana, T., C. Rahukumar, and S. Shivaji (2005), Extremophilic microbes: Diversity and perspectives, Curr. Sci., 89(1), 78-90.

Scambelluri, M., E. H. Hoogerduijn Strating, G. B. Piccardo, R. L. M. Vissers, and E. Rampone (1991), Alpine olivine and titanian clinohumite bearing assemblages in the ErroTobbio peridotite, J. Metamorph. Geol., 9, 79-91.

Schwarcz, H. P., R. S. Harmon, P. Thompson, and D. C. Ford (1976), Stable isotope studies of fluid inclusions in speleothems and their paleoclimatic significance, Geochim. Cosmochim. Acta, 40, 657-665.

Schwarzenbach, E. M. (2011), Serpentinization, fluids and life: Comparing carbon and sulfur cycles in modern and ancient environments, PhD thesis, 240 pp., ETH Zurich, Zurich, Switzerland.

Shaw, S., S. M. Clark, and C. M. B. Henderson (2000), Hydrothermal formation of the calcium silicate hydrates, tobermorite (Ca5Si6O16(OH)2.4H2O) and xonotlite (Ca6Si6O17(OH)2.4H2O): An in-situ synchrotron study, Chem. Geol., 167, 129-140.

Shelton, A. W., and S. S. Egan (1991), The obduction of the northern Oman ophiolite-Crustal loading and flexure, in Ophiolite Genesis and Evolution of Oceanic Lithosphere, edited by T. J. Peters et al., pp. 469-483, Kluwer Acad, Dordrecht, Netherland.

Shock, E. L. (1992), Chemical environments of submarine hydrothermal systems, in Marine Hydrothermal Systems and the Origin of Life, edited by N. G. Holm, pp. 67-107, Kluwer Acad., Dordrecht, Netherlands.

Shock, E. L., and M. D. Schulte (1998), Organic synthesis during fluid mixing in hydrothermal systems, J. Geophys. Res., $103,28,513-28,527$.

Stanger, G. (1986), The hydrology of the Oman mountains, $\mathrm{PhD}$ thesis, The Open Univ., U. K.

Stanger, G., and C. Neal (1984), A new occurrence of suolunite, from Oman, Mineral. Mag., 48, 143-146.

Vanossi, M., L. Cortesogno, B. Galbiati, B. Messiga, G. Piccardo, and R. Vannucci (1984), Geologia delle Alpi Liguri: dati, problemi, ipotesi, Mem. della Soc. Geol. Ital., 28, 5-75.

Walter, L. M. (1986), Relative efficiency of carbonate dissolution and precipitation during diagenesis: A progress report on the role of solution chemistry, in Roles of Organic Matter in Sediment Diagenesis, edited by D. L. Gautier, Soc. Econ. Paleontol. Mineral. Spec. Publ., 38, 1-11.

Wenk, H.-R., and A. Bulakh (2006), Minerals: Their Constituents and Origin, 646 pp., Cambridge Univ. Press, New York, New York.

Weyhenmeyer, C. E., S. J. Burns, H. N. Waber, P. G. Macumber, and A. Matter (2002), Isotope study of moisture sources, recharge areas, and groundwater flow paths within the eastern Batinah coastal plain, Sultanate of Oman, Water Resour. Res., 38(10), 1184, doi:10.1029/2000WR000149. 